\title{
FORMAS DE TRATAMENTO NO LIMIAR DO SÉCULO XX: UMA ANÁLISE SOCIOPRAGMÁTICA
}

\section{FORMS OF TREATMENT AT THE TURN OF THE 20TH CENTURY: A SOCIOPRAGMATIC ANALYSIS}

\author{
Marinalda Freitas Valentim \\ Universidade Estadual de Feira de Santana \\ Feira de Santana, Bahia, Brasil \\ Mariana Fagundes de Oliveira Lacerda \\ Universidade Estadual de Feira de Santana \\ Feira de Santana, Bahia, Brasil \\ Zenaide de Oliveira Novais Carneiro \\ Universidade Estadual de Feira de Santana \\ Feira de Santana, Bahia, Brasil
}

RESUMO: A partir de uma perspectiva sociopragmática, esta pesquisa analisa o uso das formas tratamentais na posição de sujeito pleno, nas Cartas para Severino Vieira, Governador da Bahia (1901-1902). Busca-se observar a distribuição das estratégias de tratamento, conforme a situação comunicativa que se estabelece entre remetente e destinatário, de acordo com a Teoria do Poder e Solidariedade (BROWN; GILMAN, 1960). A natureza da relação estabelecida entre os remetentes e o Governador Severino Vieira foi classificada, na sua maioria, como assimétrica ascendente, o que explica a alta ocorrência da forma nominal Vossa Excelência. Esse resultado confirma a ideia de que há uma estreita relação entre formas de tratamento e papeis sociais.

PALAVRAS-CHAVE: Pronomes de tratamento; Cartas pessoais do século XX; Português Brasileiro.

ABSTRACT: From a sociopragmatic perspective, this research analyzes the use of the treatment forms in the position of full subject, in the Letters to Severino Vieira Governador da Bahia (1901-1902). In this way, it is sought to observe the distribution of treatment strategies according to the communicative situation established between sender and recipient, according to the theory of Power and Solidarity (BROWN, GILMAN, 1960). The nature of the relationship established between the senders and the Governor Severino Vieira was classified, for the 
most part, as ascending asymmetry, which explains the high occurrence of the nominal form of Your Excellency. This result confirms the idea that there is a close relationship between forms of treatment and social roles.

KEYWORDS: Treatment methods; Personal letters of the twentieth century; Brazilian portuguese. 


\section{CONSIDERAÇÕES INICIAIS}

Este artigo apresenta formas de tratamento, na posição de sujeito pleno, usadas na escrita brasileira do início do século XX, tendo por base uma amostra constituída por 102 cartas, enviadas para Severino Vieira, entre 1901 a 1902, majoritariamente por amigos e correligionários ${ }^{1}$. Essas cartas apresentam uma condição sui generis, porque, apesar de serem dirigidas a uma pessoa em exercício de mandato, o que as enquadraria como de circulação oficial - da administração pública, nos termos de Barbosa (1999, p. 147) -, têm características de documentos de circulação privada, que incluem os da administração privada e os particulares. Há uma mistura na forma com a qual os remetentes se referem ao destinatário, Severino Vieira, variando de um certo grau de cerimônia até uma forma mais íntima, como se verá no Quadro $1^{2}$.

As diferenças nas formas de tratamento entre o português europeu contemporâneo $(\mathrm{PE})$ e o português brasileiro $(\mathrm{PB})^{3}$ têm sido bastante discutidas,

\footnotetext{
${ }^{1}$ Faz parte de um conjunto de 500 cartas, editadas em versão semidiplomática facsimilar, por Carneiro (2005), organizado da seguinte forma: Parte 1: 208 cartas (1-208) escritas por 114 remetentes para vários destinatários; Parte 2: 102 cartas (209-310) enviadas a Severino Vieira por 60 remetentes, considerada aqui (p. 1134-1548); Parte 3: 190 carta (311-500) escritas por 43 sertanejos baianos que escreveram ao "coronelbarão" de Jeremoabo, Cícero Dantas Martins. Cada uma dessas partes é precedida de um índice analítico detalhado e das fichas com informações biográficas de cada um dos remetentes. Essas cartas foram publicadas posteriormente na Coletânea Cartas Brasileiras, volume 1, pela UEFS Editora, em 2011. Atualmente estão disponíveis no projeto Vozes do Sertão em Dados: história, povos e formação do português brasileiro (Processo CNPq. 401433/2009-9 - CONSEPE 102/2009) e no projeto CE-DOHS Corpus Eletrônico de Documentos Históricos do Sertão (Processo FAPESB 5566/2010 CONSEPE 202/2010), <www.uefs.br/cedohs>, que fazem parte do Núcleo de Estudos em Língua Portuguesa (NELP) do Departamento de Letras e Artes da UEFS e são parceiros do projeto nacional, Para a História do Português Brasileiro (PHPB), que tem, entre suas agendas de pesquisa, a constituição de corpora diacrônicos de documentos de natureza vária, escritos no Brasil, a partir do século XVI; estudos de mudanças linguísticas depreendidas da análise dos corpora constituídos e a reconstrução da história social linguística do Brasil."

${ }^{2} \mathrm{Cf}$, para mais detalhamentos, o índice analítico das cartas na parte 2 do volume 2 de Carneiro (2005, p. 1.001-1.014).

${ }^{3}$ As pesquisas sobre os pronomes de tratamento no âmbito do projeto Para a História do Português Brasileiro têm sido coordenadas por Célia Lopes, da Universidade Federal do Rio de Janeiro (UFRJ), que tem por objetivo central "discutir a reorganização no sistema pronominal de $2^{\mathrm{a}}$ pessoa no português brasileiro, na posição de sujeito, por uma perspectiva diatópico-diacrônica" (LOPES et al., 2018, p. 27-28). A hipótese de partida é que diferentes regiões do Brasil adotem sistemas tratamentais diferentes. A equipe do Vozes e do CE-DOHS tem colaborado com a referida professora, por meio da análise de cartas brasileiras (especialmente de cartas baianas). Conferir alguns resultados sobre o tema com as cartas do CE-DOHS: MARTINS, M. A. et al. Para um panorama sóciodiacrônico das formas de tratamento na função de sujeito na região Nordeste.
} 
tanto do ponto de vista semântico-pragmático e/ou sociolinguístico ${ }^{4}$, quanto do ponto de vista morfossintático, especificamente no que diz respeito às mudanças na segunda pessoa, sobretudo aquelas relacionadas ao você, com implicações importantes para o $\mathrm{PB}$, como será mostrado, adiante, como parte do paradigma do voceamento. De modo geral, os resultados encontrados indicam quatro padrões: i) uso exclusivo de Vossa Excelência; ii) uso exclusivo de Vossa Senhoria; iii) uso exclusivo de Senhor; iv) uso exclusivo de você; v) mistura das formas de base nominal Senhor e você e vi) alternância de tu e vocế.

Para a descrição do uso das formas de tratamento no corpus em questão, utilizou-se, como parâmetro, a distribuição das estratégias de tratamento, conforme a situação comunicativa que se estabelece entre remetente e destinatário, de acordo com a Teoria do Poder e Solidariedade (BROWN; GILMAN, 1960).

O trabalho está assim organizado: na seção 1, apresenta-se uma breve revisão sobre as formas de tratamento no PB; na seção 2 , faz-se uma descrição do corpus de pesquisa; os resultados estão apresentados na seção 3 .

\section{AS FORMAS DE TRATAMENTO NO PORTUGUÊS BRASILEIRO}

Conforme Brown e Gilman (1960), as mudanças havidas ao longo do tempo, na estrutura da sociedade medieval estão relacionadas com a evolução das formas de tratamento. A sociedade passa, com a ascensão da burguesia, a estabelecer relações de natureza mais igualitárias; com isso, novas relações se instalam e, dessa forma, uma nova configuração no sistema pronominal acontece. Conforme os autores, no latim, havia um sistema pronominal formado apenas por

LaborHistórico, v. 1, p. 26-48, 2015. LACERDA, M. F. de O.; DE ANDRADE, A. L.; CARNEIRO, Z. de O. N. Formas tratamentais em cartas baianas: sujeito e outras funções. Cadernos de Estudos Linguísticos (UNICAMP). v.2, p. 257-276, 2016. LACERDA, M. F. de O. et al. Formas tratamentais no semiárido baiano: contribuições para uma configuração diatópico-diacrônica do sistema de tratamento do português brasileiro In: A Fala nordestina: entre a Sociolinguística e a Dialectologia. 1 ed. Salvador: Uneb, 2016, v.1, p. 32-52. TUY BATISTA, P; CARNEIRO, Z de O. N.; LACERDA, M. F. de O. A variação tu/você em relações de solidariedade: análise de uma documentação baiana epistolar do século XX. CONFLUÊNCIA. v.2, p. 100-121, 2017. LOPES, C. R.S. et al. A reorganização do sistema pronominal de $2^{\mathrm{a}}$ pessoa na história do português brasileiro: a posição de sujeito In: CASTILHO, A. (Org.). História do português brasileiro: mudança sintática das classes de palavra: perspectiva funcionalista.1 ed. São Paulo: Contexto, 2018, v.1, p. 24-141.

${ }^{4}$ Classificadas segundo o grau de intimidade, familiaridade, hierarquia, formalidade, níveis distintos de cortesia, entre diversos aspectos. Cf. Carreira (2004), para o PE, e Rodrigues (2003), para o PB.

${ }^{5}$ Trata-se de um mesmo remetente que se dirige ao mesmo destinatário em cartas distintas, uma com uso exclusivo de você e outra com uso exclusivo de $t u$. 
duas estratégias de referência ao interlocutor, a saber ${ }^{6}$ o $t u$ como indicador do singular e o uos como indicador do plural. O tratamento ao rei é um bom exemplo das consequências dessa nova estrutura social, já que, com a ampliação das suas funções - para além da função de chefe militar -, a forma uos deixou de ser suficiente para o seu trato, favorecendo o surgimento de novas formas de tratamento constituídas por Vossa + Nome, com o intuito de dar conta da nova função do ilustre interlocutor, a saber: Vossa Mercê, Vossa Senhoria, Vossa Majestade, Vossa Alteza e Vossa Excelência. Vale salientar que, quando essas formas chegaram ao Brasil, já não possuíam a mesma força cortês dos séculos passados. Para Teyssier (1997), o aparecimento das formas tratamentais nominais no português deu-se a partir de 1500, com o aparecimento das expressões Vossa Graça e Vossa Excelência, seguidas de verbo na $3^{\text {a }}$ pessoa ${ }^{7}$.

Em relação ao $\mathrm{PB}$, estudos realizados a partir de peças teatrais dos séculos XVIII e XIX descrevem os três subsistemas na posição de sujeito - tu, você, e $t u$ $\sim$ você. $\mathrm{O}$ uso de $t u$ era mais presente do que o uso de você nas relações de simetria, ou seja, entre iguais. A partir do século XIX, a forma você assume um caminho diferente do percorrido em Portugal. Nas relações assimétricas descendentes, o emprego de você era mais frequente e, no início do século $\mathrm{XX}$, ambas as formas coexistem nos mesmos contextos (SOTO, 2001, 2007; LOPES; MACHADO, 2005; RUMEU, 2008). Esses estudos mostram que era instável, no século XIX, o tratamento você, uma vez que a elite brasileira usava a forma como uma estratégia de prestígio, enquanto as classes mais populares faziam uso de você em alternância com o $t u$.

\footnotetext{
${ }^{6}$ No século IV, o paradigma muda, o vos passa a ser empregado para expressar singularidade e começa a ser empregado como forma de tratamento respeitosa, dirigida, unicamente, ao imperador romano. Na segunda metade do século XIV, a burguesia passa a competir com a nobreza, tornando-se uma nova aristocracia. Já havia no latim as expressões nominais de tratamento Maiesta Vestra e Excellentia Vestra; no entanto, só durante a idade média acontece a proliferação de tais formas, nas línguas românicas. De acordo com Cintra (1972), em 1331, já se identifica a existência de Vossa Mercê e, em 1460, tal tratamento passa a ser usado, unicamente, para o rei. Por volta de 1490, perde essa função, tendo em vista o aumento dos contextos de uso da expressão. Vossa Mercê, de onde deriva o você, gradativamente passa a ser usado como referência a outros membros da nobreza (LOPES \& DUARTE, 2002).

${ }^{7}$ Para Faraco (1996), a introdução de novas formas ocasionou, no sistema, uma instabilidade, no tocante aos paradigmas verbais e pronominais. A alta burguesia, com a expansão de seu poder econômico, fomentou, na estrutura administrativa do governo, um número maior de cargos públicos, direcionados à nova aristocracia. A nova configuração social trouxe, então, uma nova reestruturação linguística, principalmente no que se refere às novas formas de tratamento interpessoal. $\mathrm{O}$ autor propõe uma datação diferente para a inclusão das formas nominais de tratamento: em 1434, surge Vossa Senhoria; em 1442, a forma Vossa Majestade aparece; em 1450, a forma Vossa Alteza; e, por fim, em 1455, a forma Vossa Excelência. Segundo o autor, a partir do século XII, as mudanças no âmbito econômico e político de Portugal permitiram à burguesia uma ascensão social, dando a essa classe acesso à literatura.
} 
Ao analisar cartas pessoais do fim do século XIX e início do século XX, Rumeu (2008) evidencia que o emprego de você dava-se para destinatários específicos, e o seu surgimento como forma plena, quase sempre, relacionava-se à marcação de ênfase, contraste ou individualização. Nos fins do século XIX e inícios do século $\mathrm{XX}$, a forma você aparece em diferentes contextos discursivopragmáticos, característicos de formas híbridas em processo de mudança. A inclusão de você representa um reflexo da reorganização do sistema pronominal no PB (BRITO, 2001; SOTO, 2001; MACHADO, 2005; LOPES, 2008, entre outros).

Marcotulio (2010) demonstra que os pronomes de tratamento são condicionados por fatores sociolinguísticos e pragmáticos. $\mathrm{O}$ autor analisa a dinâmica das relações sociais tecidas no Brasil colonial, a partir da representação social construída pelo Vice-rei do Estado do Brasil, o Marquês do Lavradio, em sua produção escrita, nas esferas pública e privada. Sua análise é baseada em Brown e Gilman (1960), que propõem a dicotomia do Poder e da Solidariedade.

Para Brown e Gilman (1960), o tipo de relação mantida entre os interlocutores define a semântica dos pronomes de tratamento. Dessa forma, a estrutura social de que os interactantes fazem parte forneceria indícios para o estudo da variação no uso das formas de tratamento. O eixo vertical ou assimétrico - que diz respeito às relações que seriam marcadas por diferenças hierárquicas - constitui a semântica do poder. As relações ocorridas no eixo horizontal ou simétrico são consideradas, pelos autores, como pertencentes à semântica da solidariedade. A relação de poder, então, trata-se do controle, em uma dada situação de interação, que umas pessoas exercem sobre outras, o que pode resultar em uma relação assimétrica. Assim, nos seus termos, a relação de poder se estabelece sobre diferentes bases, tais como força física, riqueza, idade, sexo, papeis institucionalizados na igreja, no Estado, nas forças armadas ou na família.

Lopes (2001) fez uma readaptação terminológica dos eixos sociais: o eixo de poder compreenderia, para a autora, as relações assimétricas ascendentes, quando se dirige a alguém hierarquicamente superior, e as relações assimétricas descendentes, quando, na escala social, o interlocutor é inferior. Há, também, as relações simétricas marcadas pelas relações entres pessoas que estão em posições hierárquicas iguais.

\section{A ESCRITA EPISTOLAR: CARTAS PARA SEVERINO VIEIRA (1901-1902)}

O acervo Cartas para Severino Vieira, aqui analisado, foi doado ao acervo do IGHB $^{8}$ e encontra-se disponível no site do projeto CE-DOHS: Corpus Eletrônico de Documentos Históricos do Sertão (www.uefs.br/cedohs).

A amostra é composta por 102 cartas, enviadas a Severino Vieira por 60 remetentes (57 homens e 03 mulheres), a maioria deles letrada e, sobretudo,

\footnotetext{
${ }^{8}$ Publicadas no volume 1 da Coleção Cartas Brasileiras, cf. Carneiro (2011).
} 
citadina. São, majoritariamente, brasileiros: 8 baianos, 1 goiano, 1 mineiro, 1 paraibano, 1 paraense, 1 pernambucano, 1 piauiense, 8 cariocas, 1 potiguar e 1 sergipano, 2 brasileiros, sem especificação de naturalidade, e 16 brasileiros por inferência ${ }^{9}$. Identificam-se como amigo em $50 \%$ das correspondências dirigidas a Severino Vieira. Outras formas de tratamento utilizadas são: servo humilde, patrício e correligionário, conterrâneo, colega e amigo velho, amigo e colega, amigo e criado, compadre amigo, amigo e admirador, afilhado.

São datadas as cartas de 1901 a 1902: 41 delas, de 1901, e 58, de 1902, período que corresponde ao primeiro biênio do mandato de Severino Vieira, Governador da Bahia (1901-1904) ${ }^{10}$.

São cartas sobre assuntos privados. São $32 \%$ de cartas particulares de um procurador seu, no Rio de Janeiro, F. Mendes da Rocha. A maior parte, entretanto, $39 \%$, é composta por cartas com pedidos vários, principalmente para ocupação de cargos; 4,8\% se tratam de cartas com agradecimentos por solicitações atendidas, no plano particular. As cartas que abordam assuntos estritamente pessoais somam 23,3\%. E há uma carta informando sobre uma exposição estrangeira no Brasil, $0,96 \%$.

O termo de doação escrito por Wanderley Pinho, transcrito abaixo conforme o original, é bem esclarecedor do histórico da documentação (sem destaque no original):

\footnotetext{
${ }^{9}$ E, ainda, 2 estrangeiros: John T. Lewis (carta $\left.n^{\circ} 280\right)$ e M. Wicks (cartas $n^{o} 292$ e $n^{o}$ 293), não consideradas na análise.

${ }^{10}$ Severino Vieira nasceu em 08 de junho de 1849, na Vila de Ribeira do Conde, na Bahia, e faleceu em 23 de setembro de 1917. Exerceu ainda o cargo de Ministro de Viação e Obras Públicas, no governo de Campos Sales, além de outros cargos públicos.
} 
As informações sinte Offereço para o archivo do Instituto, uma pequena collecção de cartas, escriptas ao Governador Severino Vieira. Fôram ellas encontradas um dia, quando meu Pae, o Dr. Araújo Pinho, era governador, dentro de um dos moveis do Palacio das Mercês. A residência do governador do estado, como todos sabem, era o Palacio da Victoria, onde moraram, durante seus quatriennios - Severino Vieira e José Marcellino. Arruinada aquella casa, fizeram-se obras de adaptação na das Mercês (hoje Secretaria da Agricultura), para onde foi transferido o mobiliário da Victoria. Certa manhã um creado, tendo afastado a tampa de mármore de um pequeno armário fechado, encontrou um masso de documentos que são estas cartas. Ellas haviam atravessado, esquecidas por Severino, todo o quatriennio José Marcelino e cerca de um anno do governo Araújo Pinho dentro daquelle movel. Levadas a meu Pae, este, verificando o que eram disse, sem lel-as: "Isto não me pertence. Amarrem e embrulhem, pondo numa das estantes do meu gabinete." Assim se fez e, amarradas como naquelle momento foram, continuaram até a dias. Tinhamos acatado até então a discreção e o respeito ao sigillo da correspondência, levados a tão estricto rigôr por meu Pae. Mas já agora, depois de tanto tempo e de desapparecidos tantos interessados nelles, esses papeis passavam á classe de documentos historicos. Foi por isso que resolvi verificar se continham algo de inconveniente em tomar o destino que agora lhes dou. Nada lhes descobri, numa rápida leitura que os impedisse de ser facultados aos pesquisadores daquellas epocas e aos curiosos daquelles homens. Assignal-o, com envaidecimento, a nobresa rara do procedimento de meu Pae. Quando aquelas cartas foram encontradas era ainda tremenda a campanha de opposição, inspirada por Severino, no Diario da Bahia. Injusta, como soem ser, em seus exageros, as lides politicas entre nós, sempre agitadas de paixão. [...] São ao todo cem cartas, Wanderley Pinho. (sem data) ${ }^{11}$.

As informações sintetizadas no Quadro 1, extraídas de Carneiro (2005, p. 63-115; 249-251; 332-372), são importantes, porque levam a compreender como as formas de tratamento são estabelecidas como recursos que "regulam" a distância entre os interlocutores, expressando-se tanto no nível do discurso quanto no nível da língua, como defende Carreira $\left(1995,2004\right.$, entre outros) ${ }^{12}$. Para a

\footnotetext{
${ }^{11}$ Embora Wanderley Pinho diga que as cartas "São ao todo cem", são103 cartas. Não foi citada por ele uma carta datada de 15 de novembro de 1901 de Saldanha. Além dessa, há duas outras cartas de F. Mendes da Rocha que também não foram referidas, uma estava totalmente danificada, razão pela qual não foi transcrita. Existe uma carta incluída na amostra que foi dirigida, originalmente, ao oficial do gabinete de Severino Vieira, Eduardo Sabóia. Uma outra correção diz respeito ao remetente M.Wicks que Wanderley Pinho identifica como Jacob, nome que consta do timbre da carta "Jacob Walter \& Cia. ${ }^{12}$ Cf. o esquema detalhado de Carreira $(1995 ; 2004)$ sobre as formas de tratamento a partir da oposição grau de "familiaridade" e "distância", no singular e no plural.
} 
autora, cada interlocutor escolhe o tratamento mais adequado ao avaliar onde se situa e a quem se dirige.

À luz da Teoria do Poder e Solidariedade (BROWN; GILMAN, 1960) que propõe relações assimétricas descendentes, isto é, relações estabelecidas de um indivíduo que está em uma posição superior para um indivíduo em posição hierarquicamente inferior, e relações assimétricas ascendentes, isto é, relações estabelecidas de um indivíduo que está em uma posição inferior para um indivíduo em posição hierarquicamente superior -, foram controlados os contextos sociais que subsidiaram as formas de referência à segunda pessoa e classificadas as relações como simétricas e assimétricas (ascendentes e descendentes); as relações estabelecidas foram, ainda, consideradas como mais e menos solidárias, levando-se em conta a relação interpessoal estabelecida: amigos próximos (mais íntimos) - mais solidárias; e amigos mais distantes (menos íntimos) - menos solidárias.

A classificação da relação interpessoal entre Severino Vieira e seus destinatários foi estabelecida a partir do assunto tratado nas missivas. Dessa forma, foram considerados como amigos próximos remetentes que trataram de assuntos pessoais (notícias sobre amigos comuns, sobre saúde etc.) e como amigos distantes remetentes que trataram de assuntos impessoais (administrativos, pedidos de favor etc.).

Esse controle foi feito, motivado pela necessidade de observar se era seguido pelos remetentes algum protocolo prévio para o uso das formas tratamentais - levando em consideração o tipo de relação havida com o governador Severino Vieira -, bem como se o uso variado das estratégias de tratamento estaria atrelado a determinadas motivações discursivo-pragmáticas. 
Quadro 1 - Síntese das informações levantadas sobre os missivistas e os tipos de relações estabelecidas com o destinatário.

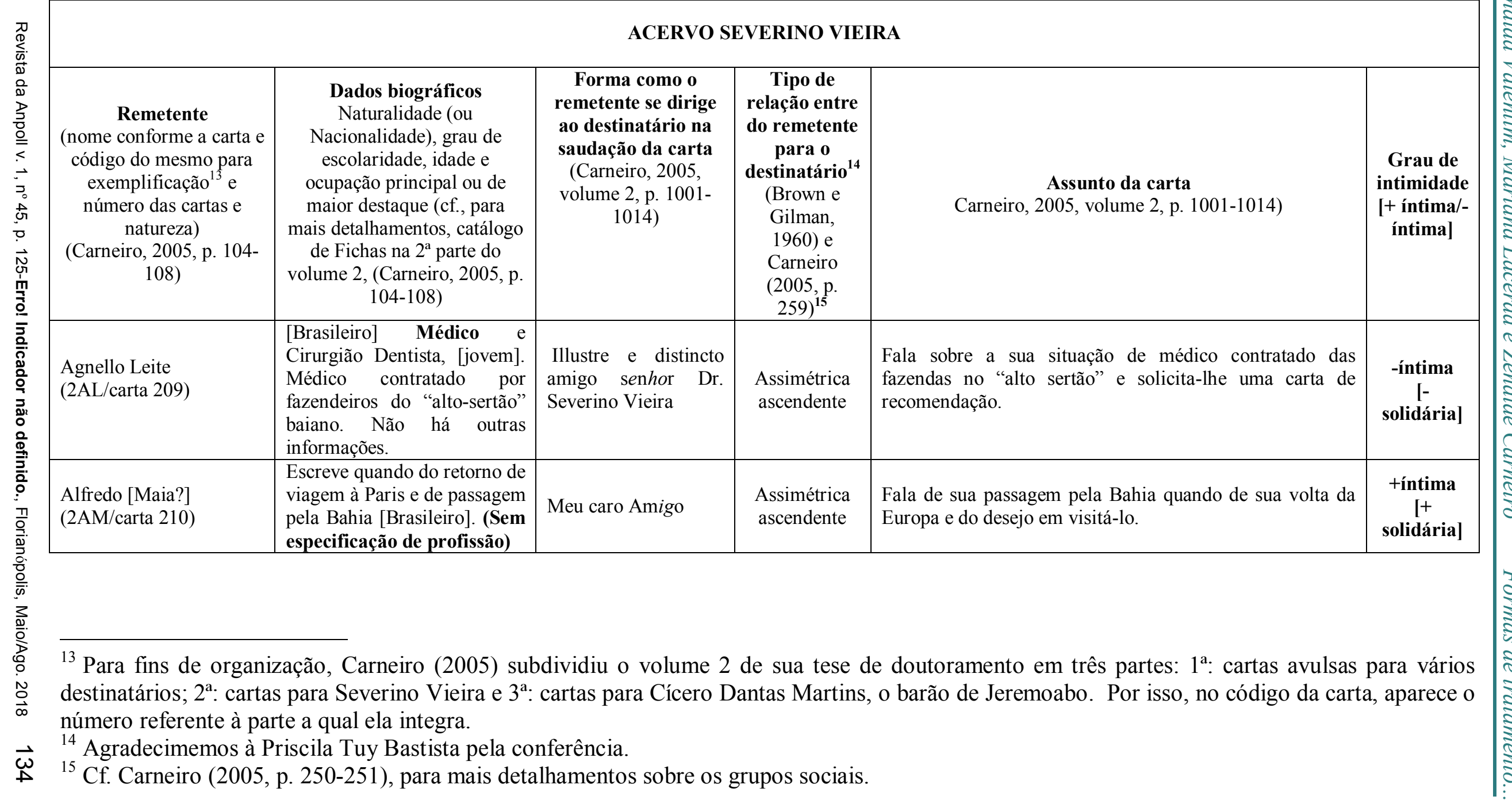




\begin{tabular}{|c|c|c|c|c|c|}
\hline $\begin{array}{l}\text { Alfredo Moreira Pinto } \\
(2 \mathrm{AMP} / \text { cartas 211e 212) }\end{array}$ & $\begin{array}{l}\text { Brasileiro (sem especificação } \\
\text { de naturalidade). Bacharel em } \\
\text { Letras (Escola Naval), } \\
\text { [maduro]. Geógrafo. }\end{array}$ & $\begin{array}{l}\text { Illustrissimo e } \\
\text { Excelentissimo } \\
\text { Senhor Dr. Severino } \\
\text { Vieira }\end{array}$ & $\begin{array}{l}\text { Assimétrica } \\
\text { ascendente }\end{array}$ & $\begin{array}{l}\text { Solicita o envio da relação das cidades, vilas e distritos } \\
\text { criados nos últimos } 4 \text { anos a fim de que o mesmo possa } \\
\text { inserir esses dados no } 1^{\circ} \text { volume do "Suplemento de } \\
\text { Dicionário Geográfico", em fase de envio para publicação. } \\
\text { (Carta 211) } \\
\text { Queixa-se do desprezo pelo qual vem sofrendo de seus } \\
\text { concidadãos sobre a falta de empenho na publicação do } \\
\text { seu "Dicionário Geográfico do Brasil", a despeito dos } \\
\text { elogios que recebeu do exterior, e comunica-lhe o envio de } \\
\text { um outro trabalho seu sobre a cidade de S. Paulo. (Carta } \\
\text { 212) }\end{array}$ & $\begin{array}{l}\text {-íntimas } \\
\text { - solidária }\end{array}$ \\
\hline $\begin{array}{l}\text { Alfredo Pinto } \\
(2 \mathrm{AP} / \text { carta } 213)\end{array}$ & $\begin{array}{l}\text { Estudante da Escola Naval, } \\
\text { jovem. Estudante Não há } \\
\text { outras informações. }\end{array}$ & Dr. Severino & $\begin{array}{l}\text { Assimétrica } \\
\text { ascendente }\end{array}$ & $\begin{array}{l}\text { Solicita-lhe que o recomende junto à "Escola Naval" no } \\
\text { seu exame final. }\end{array}$ & $\begin{array}{l}\text {-íntima } \\
\text { [- } \\
\text { solidária] }\end{array}$ \\
\hline $\begin{array}{lrr}\text { Alipio } & \text { de } & \text { Miranda } \\
\text { Ribeiro } & (2 \mathrm{AMR} / \text { carta } \\
214) & \end{array}$ & $\begin{array}{l}\text { Mineiro. (Faculdade de } \\
\text { Medicina do Rio de Janeiro, } \\
\text { curso incompleto), } 27 \text { anos. } \\
\text { Zoólogo. }\end{array}$ & $\begin{array}{l}\text { Excelentissimo Sr. } \\
\text { Governador do } \\
\text { Estado da Bahia }\end{array}$ & $\begin{array}{l}\text { Assimétrica } \\
\text { ascendente }\end{array}$ & $\begin{array}{l}\text { Comunica o envio, para distribuição em cidades e } \\
\text { entidades baianas, do "XI volume dos Archivos do } \\
\text { Museu". }\end{array}$ & $\begin{array}{l}\text {-íntima } \\
\text { [- } \\
\text { solidária] }\end{array}$ \\
\hline $\begin{array}{lc}\text { Alvaro } & \text { Appio de } \\
\text { Carvalho } & (2 \mathrm{AAC} / \text { carta } \\
215) & \end{array}$ & $\begin{array}{l}\text { Brasileiro (sem especificação } \\
\text { de naturalidade), [maduro]. } \\
\text { Presidente do Partido } \\
\text { Republicano. }\end{array}$ & $\begin{array}{l}\text { Illustrissimo } \quad \mathrm{e} \\
\text { Excelentissimo Sr. Dr } \\
\text { Victorino } \quad \text { Por } \\
\text { Severino] Vieira }\end{array}$ & $\begin{array}{l}\text { Assimétrica } \\
\text { ascendente }\end{array}$ & $\begin{array}{l}\text { Fala da Comissão do "Partido Republicano Mineiro" e } \\
\text { pede que o indique para fazer parte da mesma. }\end{array}$ & $\begin{array}{c}\text {-íntima } \\
\text { [- } \\
\text { solidária] }\end{array}$ \\
\hline $\begin{array}{l}\text { Anna } \\
\text { [TheophilaFilgueiras] } \\
\text { Autran (2ATFA/carta } \\
216)\end{array}$ & $\begin{array}{l}\text { Baiana. [Culta], } 45 \text { anos. } \\
\text { Escritora. }\end{array}$ & $\begin{array}{l}\text { Illustissimo } \\
\text { Excelentissimo } \\
\text { Senhor Dr. Severino } \\
\text { Vieira }\end{array}$ & $\begin{array}{l}\text { Assimétrica } \\
\text { ascendente }\end{array}$ & $\begin{array}{l}\text { Oferece a sua cooperação ao governador em prol da } \\
\text { candidatura do Dr. Roiz Alves }\end{array}$ & $\begin{array}{c}\text {-íntima } \\
\text { [- } \\
\text { solidária] }\end{array}$ \\
\hline $\begin{array}{l}\text { Antonio } \quad \text { Augusto } \\
\text { Cardoso de Castro } \\
(2 \mathrm{AACC} / \text { carta 217) }\end{array}$ & $\begin{array}{l}\text { Brasileiro (Carioca?). } \\
\text { [Bacharel]. Secretário da } \\
\text { Estrada de Ferro D. Pedro II, } \\
\text { [maduro]. Jornalista. }\end{array}$ & $\begin{array}{l}\text { Excelentissimo } \\
\text { amigo Senhor Doutor } \\
\text { Severino Vieira }\end{array}$ & $\begin{array}{l}\text { Assimétrica } \\
\text { ascendente }\end{array}$ & $\begin{array}{l}\text { Lamenta o fato do governador não aceitá-lo entre seus } \\
\text { amigos. }\end{array}$ & $\begin{array}{c}\text { +íntima } \\
{[+} \\
\text { solidária] }\end{array}$ \\
\hline
\end{tabular}




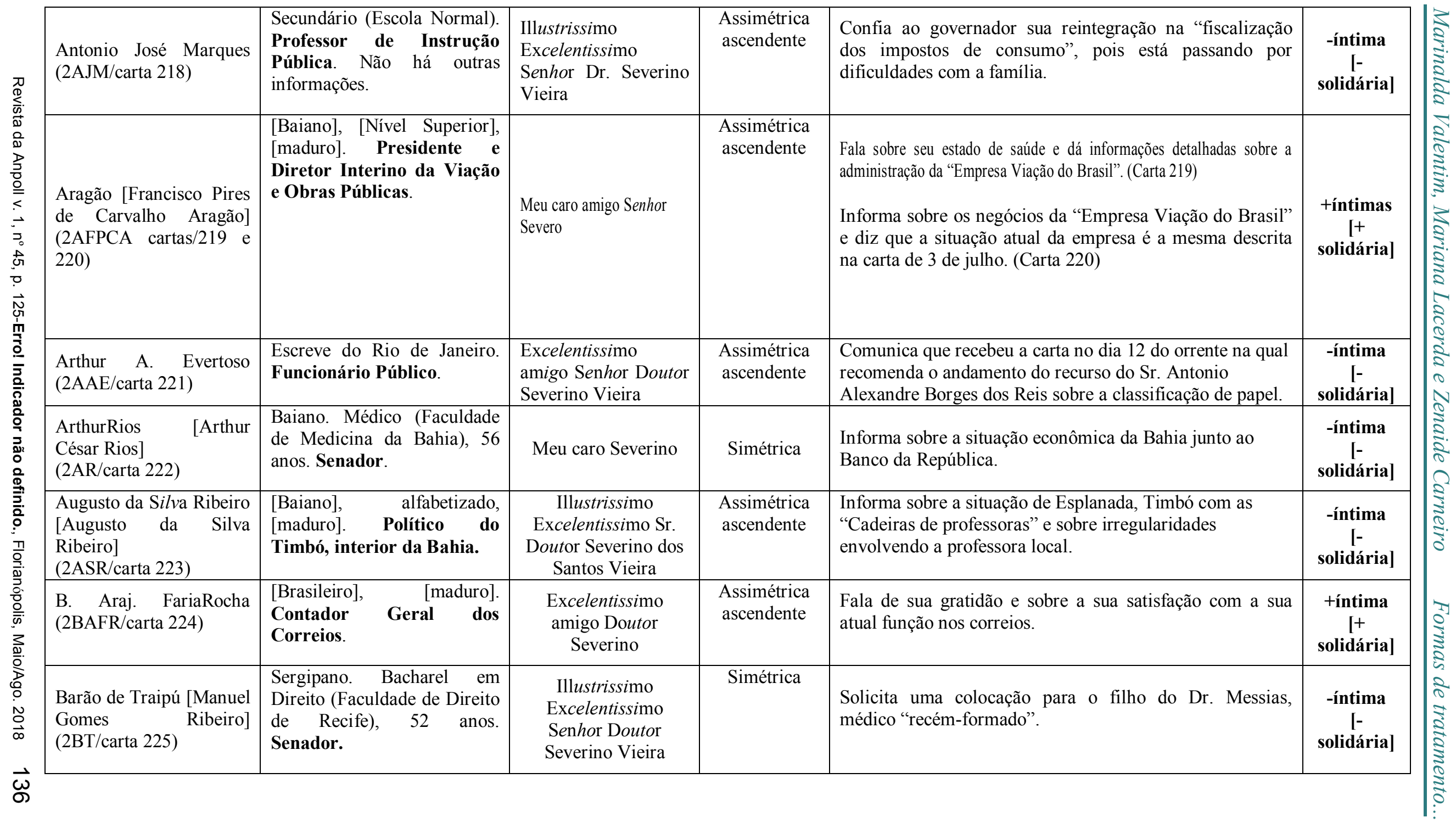




\begin{tabular}{|c|c|c|c|c|c|}
\hline $\begin{array}{lr}\text { Belisario } & \text { Fernandes } \\
\text { Tavora. } & (2 \mathrm{BFT} / \text { carta } \\
\text { 226) } & \end{array}$ & $\begin{array}{l}\text { [Brasileiro]. Médico } \\
\text { Veterinário. Participou da } 3^{\mathrm{a}} \\
\text { Delegação Auxiliar. }\end{array}$ & $\begin{array}{l}\text { Excelentissimo } \\
\text { Amigo Dr Severino } \\
\text { Vieira }\end{array}$ & $\begin{array}{l}\text { Assimétrica } \\
\text { ascendente }\end{array}$ & $\begin{array}{l}\text { Fala sobre o amigo em comum, Eduardo Sabóia, em sua } \\
\text { recente viagem ao Norte. Convida o amigo para que batize } \\
\text { a sua "filhinha Idalina" nascida em } 20 \text { de abril último. } \\
\text { Fala, também, sobre a sua difícil situação financeira. }\end{array}$ & $\begin{array}{l}\text { +íntima } \\
{[+} \\
\text { solidária] }\end{array}$ \\
\hline $\begin{array}{l}\text { Calogeras [João Pandiá } \\
\text { Calógeras] (2JPC/cartas } \\
227,228 \text { e 229) }\end{array}$ & $\begin{array}{l}\text { Carioca. Bacharel em } \\
\text { Ciências } \\
\text { (Engenharia) (Escola de } \\
\text { Minas em Ouro Preto), } 32 \\
\text { anos. Ministro. }\end{array}$ & $\begin{array}{l}\text { Prezado amigo Dr. } \\
\text { Severino (carta 227) } \\
\text { Amigo Dr. Severino } \\
\text { (cartas 228 e 229) }\end{array}$ & Simétrica & $\begin{array}{l}\text { Comunica o envio do último relatório da secretaria das } \\
\text { finanças. (Carta 227) } \\
\text { Fala sobre o pedido de amigos europeus a respeito da } \\
\text { situação financeira do governo baiano a fim de que se } \\
\text { avalie sobre futuros investimentos de capital estrangeiro. } \\
\text { (Carta 228) } \\
\text { Informa sobre os relatórios recebidos a respeito da } \\
\text { administração do governo baiano, referente ao ano de } \\
\text { 1900, solicita os relatórios ao ano de 1901, assim que } \\
\text { sejam publicados. (Carta 229) }\end{array}$ & $\begin{array}{l}\text {-íntima } \\
{[-} \\
\text { solidária] }\end{array}$ \\
\hline $\begin{array}{l}\text { Carolina Buarque Pinto } \\
\text { Guimarães } \\
\text { (2CBPG/cartas 230, } 231 \\
\text { e 232) }\end{array}$ & $\begin{array}{lr}\text { [Brasileira], } & \text { alfabetizada } \\
\text { [madura]. } & (\text { Sem } \\
\text { especificação de profissão) }\end{array}$ & $\begin{array}{l}\text { Senhor Dr. Severino } \\
\text { Vieira (cartas } 230 \text { e } \\
\text { 231) } \\
\text { Senhor Dr. Severino } \\
\text { Vieira (carta 232) }\end{array}$ & $\begin{array}{l}\text { Assimétrica } \\
\text { ascendente }\end{array}$ & $\begin{array}{l}\text { Pede, com urgência, uma carta de recomendação para o } \\
\text { seu filho mais velho, Afonso. (Carta 230) } \\
\text { Fala sobre a carta de recomendação para o seu filho } \\
\text { Afonso junto ao Dr. Leitão da Cunha e ao Sr. Honório } \\
\text { Muniz. (Carta 231) } \\
\text { Pede em favor da permanência do seu irmão João para o } \\
\text { posto de "pretor da } 14^{\text {a }} \text { Pretoria d'esta Capital" uma vez } \\
\text { que está vencendo o seu segundo quatriênio, em } 16 \text { de } \\
\text { dezembro próximo. (Carta 232) }\end{array}$ & $\begin{array}{l}\text {-íntimas } \\
{[-} \\
\text { solidária] }\end{array}$ \\
\hline $\begin{array}{l}\text { Gonçalves } \\
\text { (2DGM/carta }\end{array}$ & $\begin{array}{l}\text { Baiano. Bacharel em } \\
\text { Ciências Matemáticas } \\
\text { (Engenharia) (inicia o curso } \\
\text { na Escola Militar da Praia } \\
\text { Vermelha, concluindo-o na } \\
\text { Escola Central de Paris), } 64 \\
\text { anos. Diretor do Imperial } \\
\text { Instituto de Agricultura. }\end{array}$ & $\begin{array}{l}\text { Illustrissimo e } \\
\text { Excelentissimo } \\
\text { Senhor }\end{array}$ & $\begin{array}{l}\text { Assimétrica } \\
\text { ascendente }\end{array}$ & $\begin{array}{l}\text { Solicita uma solução para problemas com o fornecimento } \\
\text { de água na capital. }\end{array}$ & $\begin{array}{c}\text {-íntima } \\
{[-} \\
\text { solidária] }\end{array}$ \\
\hline
\end{tabular}




\begin{tabular}{|c|c|c|c|c|c|}
\hline $\begin{array}{l}\text { Domingos C. de Moraes } \\
(2 \mathrm{DCM} / \text { carta } 234)\end{array}$ & $\begin{array}{l}\text { Alfabetizado, [maduro]. } \\
\text { Político local. }\end{array}$ & $\begin{array}{l}\text { Excelentissimo } \\
\text { Amigo Doutor } \\
\text { Severino Vieira }\end{array}$ & $\begin{array}{l}\text { Assimétrica } \\
\text { ascendente }\end{array}$ & $\begin{array}{l}\text { Solicita que consiga, a pedido de um amigo, o Dr. Miguel } \\
\text { C. Vila Nova, médico residente em Batatas, a nomeação } \\
\text { para Juiz de Direito, do cunhado desse, o Dr. João da } \\
\text { Motta Ramos Costa. }\end{array}$ & $\begin{array}{l}\text {-íntima } \\
{[-} \\
\text { solidária] }\end{array}$ \\
\hline $\begin{array}{l}\text { Domingos Olympio } \\
(2 \mathrm{DO} / \text { carta } 235)\end{array}$ & $\begin{array}{l}\text { Escreve do Rio de Janeiro. } \\
\text { Não há outras informações. } \\
\text { (Sem especificação de } \\
\text { profissão) }\end{array}$ & $\begin{array}{c}\text { Meu caro Saboya } \\
\text { (Carta remetida a } \\
\text { Saboya e reenviada, } \\
\text { posteriormente, a } \\
\text { Severino Vieira) }\end{array}$ & $\begin{array}{l}\text { Assimétrica } \\
\text { ascendente }\end{array}$ & $\begin{array}{l}\text { Vem lembrar a promessa feita e reclama o fato de não ter } \\
\text { sido entregue o dinheiro ao Sr. João Cerqueira. }\end{array}$ & $\begin{array}{l}\text {-íntima } \\
\text { [- } \\
\text { solidária] }\end{array}$ \\
\hline $\begin{array}{l}\text { Dr. Emilio Teixeira dos } \\
\text { Santos Imbassahy } \\
(2 \text { ETSI carta/236) }\end{array}$ & $\begin{array}{l}\text { [Baiano], [Brasileiro]. [Nível } \\
\text { Superior], } \quad \text { [maduro]. } \\
\text { Intendente } \\
\text { Caravelas/Ba. }\end{array}$ & $\begin{array}{l}\text { Illustrissimo Amigo } \\
\text { Excelentissimo } \\
\text { Senhor Dr. Severino } \\
\text { Vieira }\end{array}$ & $\begin{array}{l}\text { Assimétrica } \\
\text { ascendente }\end{array}$ & $\begin{array}{l}\text { Solicita ao Dr. Severino a reintegração do amigo Coronel } \\
\text { Antonio Jacinto junto à Recebedoria Fiscal. }\end{array}$ & $\begin{array}{l}\text {-íntima } \\
{[-} \\
\text { solidária] }\end{array}$ \\
\hline $\begin{array}{l}\text { Dr. Henrique Autran } \\
(2 \mathrm{HA} / \text { carta } 237)\end{array}$ & $\begin{array}{lr}\text { Pernambucano. } & \text { [Nível } \\
\text { Superior], [maduro]. } & \text { (Sem } \\
\text { especificação de profissão) }\end{array}$ & $\begin{array}{l}\text { Excelentissimo } \\
\text { Senhor Doutor } \\
\text { Severino Vieira }\end{array}$ & $\begin{array}{l}\text { Assimétrica } \\
\text { ascendente }\end{array}$ & $\begin{array}{l}\text { Agradece ao governador pela sua interferência na } \\
\text { nomeação do "Presidente da República" para o "Cargo de } \\
\text { Delegado de Saúde". }\end{array}$ & $\begin{array}{l}\text {-íntima } \\
{[-} \\
\text { solidária] }\end{array}$ \\
\hline $\begin{array}{l}\text { Dr. Joaquim Carlos } \\
\text { Travassos (2JCT/carta } \\
\text { 238) }\end{array}$ & $\begin{array}{l}\text { Carioca. Médico (Faculdade } \\
\text { de Medicina da Bahia), } \\
\text { [maduro]. Senador. }\end{array}$ & $\begin{array}{l}\text { Excelentissimo } \\
\text { Amigo Senhor. Dr. } \\
\text { Severino Vieira }\end{array}$ & Simétrica & $\begin{array}{l}\text { Solicita informações sobre os originais de suas } \\
\text { conferências, confiadas ao mesmo, para que possa publicá- } \\
\text { las com outras verbas, uma vez que a promessa feita pelo } \\
\text { amigo não foi cumprida. }\end{array}$ & $\begin{array}{l}\text {-íntima } \\
{[-} \\
\text { solidária] }\end{array}$ \\
\hline $\begin{array}{l}\text { Eduardo [Pires] Ramos } \\
(2 \mathrm{EPR} / \text { carta 239) }\end{array}$ & $\begin{array}{l}\text { Baiano. Bacharel em Direito } \\
\text { (Faculdade de Direito de } \\
\text { Recife), } 47 \text { anos. Senador. }\end{array}$ & Caro Dr. Severino & Simétrica & $\begin{array}{l}\text { Solicita uma indicação junto ao Dr. Campo Salles para que } \\
\text { consiga uma colocação como secretário de legação. }\end{array}$ & $\begin{array}{l}\text {-íntima } \\
\text { [- } \\
\text { solidária] }\end{array}$ \\
\hline $\begin{array}{l}\text { Epitacio Pessoa } \quad(2 \mathrm{EP} \\
\text { cartas/240 e } 241)\end{array}$ & $\begin{array}{l}\text { Paraibano. Bacharel em } \\
\text { Direito (Faculdade de Direito } \\
\text { de Recife), } 36 / 37 \text { anos. } \\
\text { Presidente da República. }\end{array}$ & $\begin{array}{l}\text { Meu caro Severino } \\
\text { (cartas } 241 \text { e } 242 \text { ) }\end{array}$ & Simétrica & $\begin{array}{l}\text { Solicita ajuda para livrar Ramiro Bezerra, ex-conferente da } \\
\text { alfândega do Rio, da acusação falsa do crime de } \\
\text { contrabando, junto ao Supremo Tribunal Federal. (Carta } \\
\text { 240) } \\
\text { Solicita que o amigo recomende seu sobrinho junto ao Dr. } \\
\text { Arlindo, diretor da na Escola Politécnica, para o exame } \\
\text { geométrico único, Aristonho Pessoa Cavalcante de } \\
\text { Albuquerque, militar empregado no comando do distrito. } \\
\text { (Carta 241) }\end{array}$ & $\begin{array}{l}\text {-íntimas } \\
{[-} \\
\text { solidária] }\end{array}$ \\
\hline
\end{tabular}




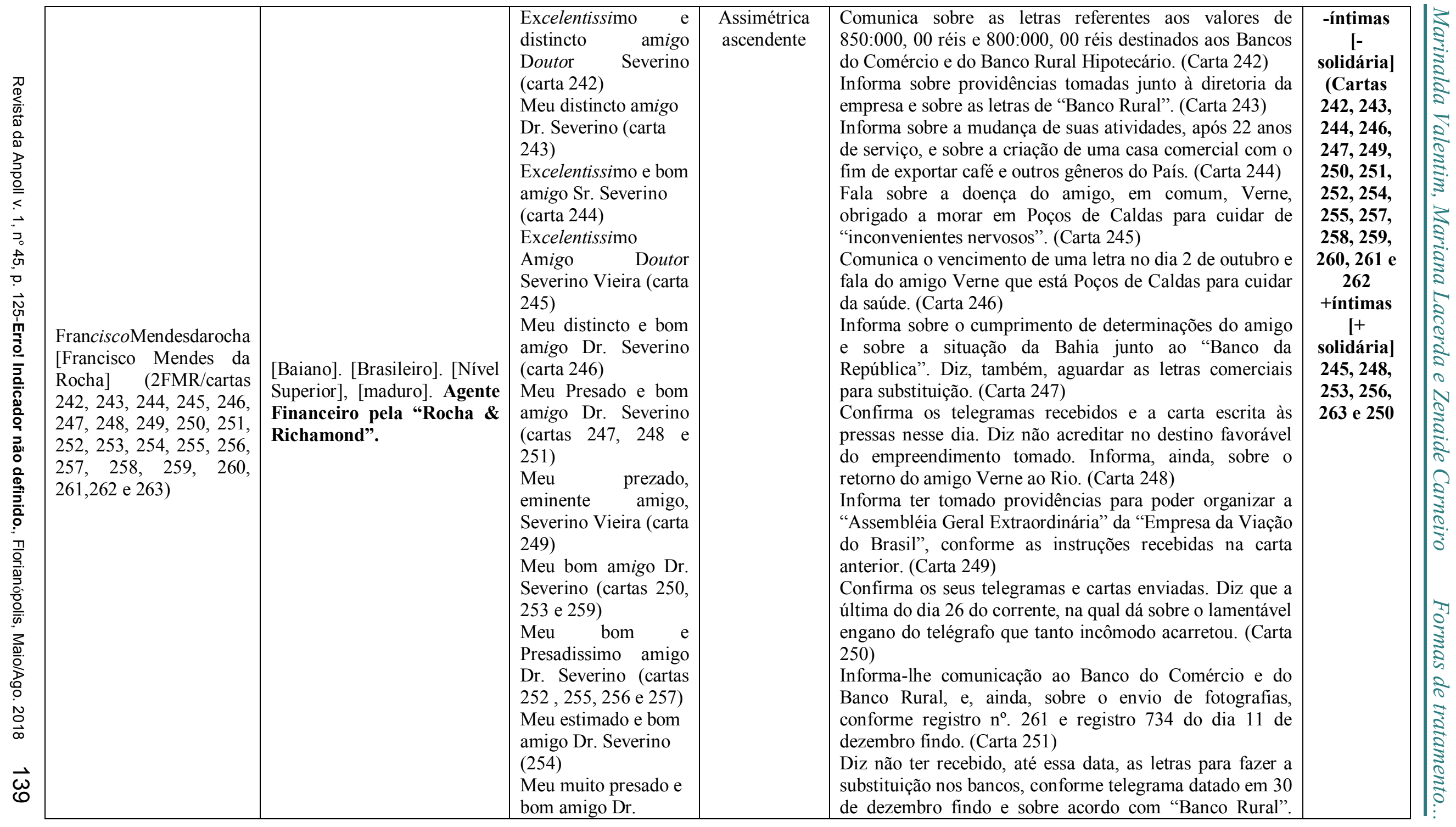




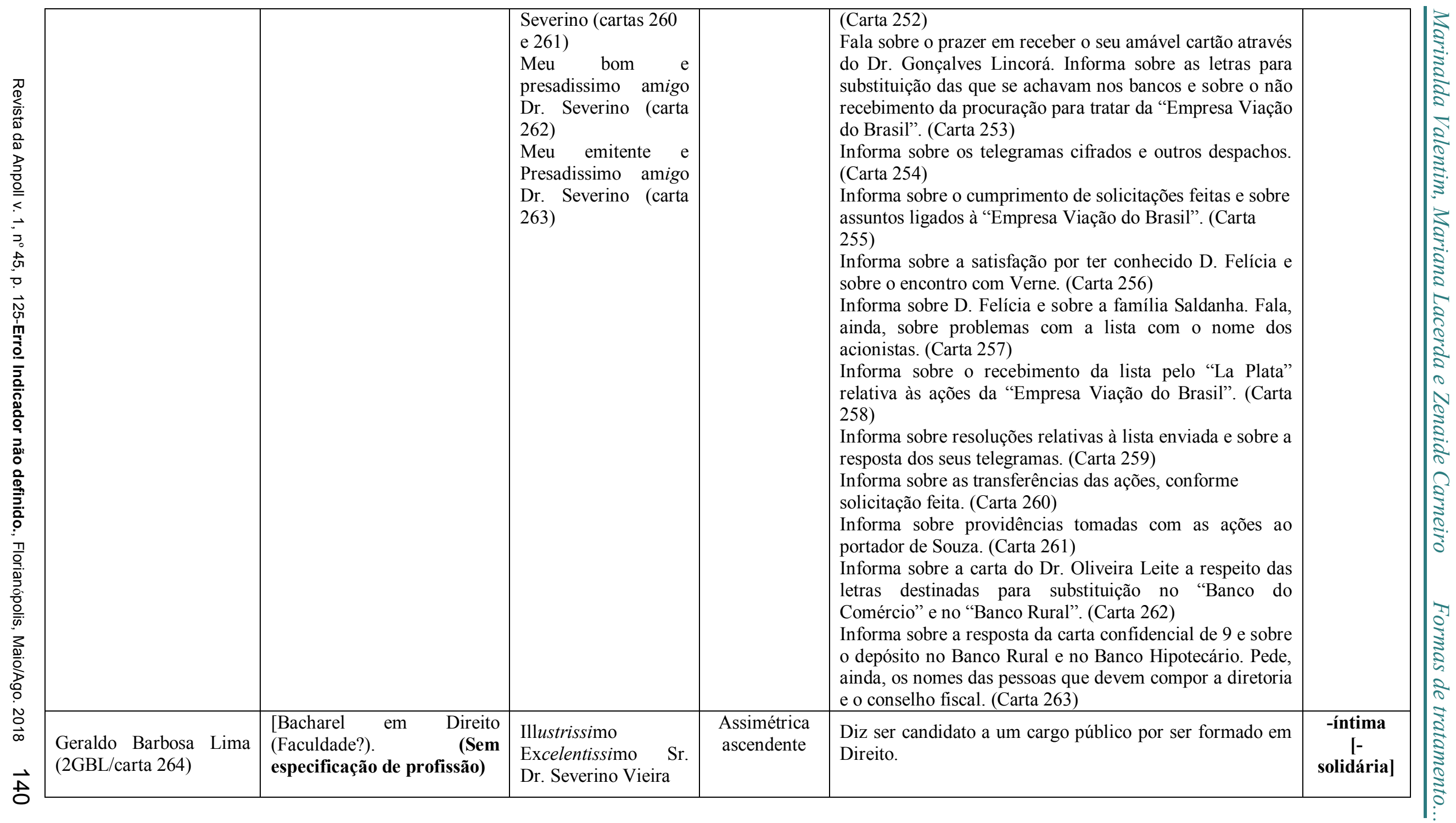




\begin{tabular}{|c|c|c|c|c|c|}
\hline $\begin{array}{l}\text { Gustavo Camara } \\
(2 \mathrm{GC} / \text { cartas } 265 \text { e } 266)\end{array}$ & $\begin{array}{l}\text { Escreve do Rio de Janeiro. } \\
\text { Não há outras informações. } \\
\text { (Sem especificação de } \\
\text { profissão) }\end{array}$ & $\begin{array}{l}\text { Meu velho e sempre } \\
\text { querido Severino } \\
\quad \text { (carta 265) } \\
\text { Meu presado amigo } \\
\text { Dr. Severino (carta } \\
\text { 266) }\end{array}$ & $\begin{array}{l}\text { Assimétrica } \\
\text { ascendente }\end{array}$ & $\begin{array}{l}\text { Informa sobre a carta recebida e convida o amigo para } \\
\text { visitar a "amada Maria de Lourdes, sua afilhadinha" } \\
\text { juntamente com a menina Felícia. (Carta 265) } \\
\text { Dá notícias sobre estado de saúde, sobre a Maria, afilhada } \\
\text { do amigo e agradece a visita da "gentilíssima D. Felícia". } \\
\text { (Carta 266) }\end{array}$ & $\begin{array}{l}\text { +intima } \\
{[+} \\
\text { solidária] }\end{array}$ \\
\hline $\begin{array}{lr}\text { HermannCarlosPalmeira } \\
\text { [Hermann } & \text { Carlos } \\
\text { Palmeira] } & (2 \mathrm{HCP} / \text { carta } \\
267) & \end{array}$ & $\begin{array}{l}\text { Escreve do Rio de Janeiro. } \\
\text { (filho de um amigo de } \\
\text { Severino). Não há outras } \\
\text { informações. } \\
\text { especificação de profissão) }\end{array}$ & $\begin{array}{l}\text { Excelentissimo } \\
\text { Senhor Dr. Severino } \\
\text { Vieira }\end{array}$ & $\begin{array}{l}\text { Assimétrica } \\
\text { ascendente }\end{array}$ & $\begin{array}{c}\text { Agradece ao Dr. Severino pelo telegrama de felicitações } \\
\text { pelo casamento e lamenta o extravio da carta de } \\
\text { agradecimento. }\end{array}$ & $\begin{array}{l}\text { +intima } \\
{[+} \\
\text { solidária] }\end{array}$ \\
\hline $\begin{array}{l}\text { Irineu Machado } \\
(2 \mathrm{IM} / \text { cartas 268 e 269) }\end{array}$ & $\begin{array}{l}\text { Nível superior. Político. Não } \\
\text { há outras informações. }\end{array}$ & $\begin{array}{l}\text { Presado amigo echefe } \\
\text { sr. dr. Severino (carta } \\
\text { 268) } \\
\text { Meu bom amigo e } \\
\text { chefe dr. Severino } \\
\text { Vieira (carta 269) } \\
\end{array}$ & $\begin{array}{l}\text { Assimétrica } \\
\text { ascendente }\end{array}$ & $\begin{array}{l}\text { Dá notícias sobre o "Parecer de Procurador Geral } \\
\text { Conselheiro Villaboni" que diz não ser das melhores. } \\
\text { (Carta 268) } \\
\text { Apresenta o compadre Tenente Fortunato Dias que está } \\
\text { desempregado. (Carta 269) }\end{array}$ & $\begin{array}{l}\text {-íntimas } \\
{[+} \\
\text { solidária] }\end{array}$ \\
\hline $\begin{array}{l}\text { J. B. Lacerda [João } \\
\text { Batista de Lacerda] } \\
\text { (2JBL/carta 271) }\end{array}$ & $\begin{array}{l}\text { Carioca. Médico. } 46 \text { anos. } \\
\text { Sub-Diretor do Laboratório } \\
\text { de Fisiologia Experimental. }\end{array}$ & $\begin{array}{l}\text { Excelentissimo Sr. } \\
\text { Dr. Severino Vieira }\end{array}$ & $\begin{array}{l}\text { Assimétrica } \\
\text { ascendente }\end{array}$ & $\begin{array}{l}\text { Diz ter sido procurado pelo Sr. Dr. Tosta, deputado geral } \\
\text { pela Bahia, o qual apresentou o telegrama do amigo que } \\
\text { pedia a remessa de vacina anti-carbunculosa. }\end{array}$ & $\begin{array}{l}\text {-íntima } \\
{[+} \\
\text { solidária] }\end{array}$ \\
\hline $\begin{array}{l}\text { João Cordeiro da Graça } \\
\text { (2JCG/carta 270) }\end{array}$ & 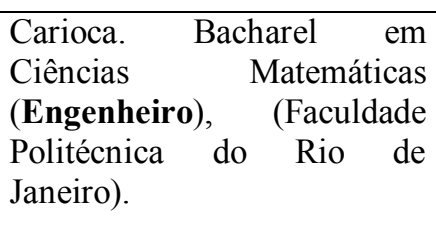 & $\begin{array}{l}\text { Amigo Senhor. Dr. } \\
\text { Severino Vieira }\end{array}$ & $\begin{array}{l}\text { Assimétrica } \\
\text { ascendente }\end{array}$ & $\begin{array}{l}\text { Comunica ao Governador que não foi possível cumprir o } \\
\text { solicitado. }\end{array}$ & $\begin{array}{c}\text {-íntima } \\
{[-} \\
\text { solidária] }\end{array}$ \\
\hline
\end{tabular}




\begin{tabular}{|c|c|c|c|c|c|}
\hline $\begin{array}{l}\text { João [Käpk ou Köpke] } \\
\text { (2JK/cartas 272, 273, } \\
274 \text { e } 275)\end{array}$ & $\begin{array}{l}\text { Carioca. Bacharel em Direito } \\
\text { (Faculdade de Direito de São } \\
\text { Paulo), } 48 \text { anos. Promotor } \\
\text { Público. }\end{array}$ & $\begin{array}{l}\text { Meu caro Severino } \\
(\text { cartas } 272,273,274 \\
\text { e } 275)\end{array}$ & $\begin{array}{l}\text { Assimétrica } \\
\text { ascendente }\end{array}$ & $\begin{array}{l}\text { Fala sobre o silencio do amigo e sobre assuntos pessoais. } \\
\text { (Carta 272) } \\
\text { Trata sobre assuntos familiares, políticos e sobre notícias a } \\
\text { respeito de assuntos comerciais. (Carta 273) } \\
\text { Trata de diversos assuntos particulares e políticos } \\
\text { envolvendo amigos em comum. (Carta 274) } \\
\text { Diz que Felícia envia abraços e fala sobre a vinda do } \\
\text { Saldanha em decorrência da moléstia de Lourdes. Informa, } \\
\text { ainda, sobre a saúde de Dória e sobre a vinda de Verne. } \\
\text { (Carta 275) }\end{array}$ & $\begin{array}{l}\text { +íntimas } \\
\text { [+ } \\
\text { solidária] }\end{array}$ \\
\hline $\begin{array}{l}\text { João Pereira Drumond } \\
\text { (2JPD/ (cartas 276) }\end{array}$ & $\begin{array}{l}\text { Escreve do Rio de Janeiro, } \\
\text { alfabetizado. Administrador } \\
\text { de Armazéns da Ilha das } \\
\text { Moças no Rio de Janeiro. }\end{array}$ & $\begin{array}{l}\text { Illustrissimo Senhor } \\
\text { Dr. Severino Vieira }\end{array}$ & $\begin{array}{l}\text { Assimétrica } \\
\text { ascendente }\end{array}$ & $\begin{array}{l}\text { Relembra a recomendação relativa ao Sr. Barrow, Gerente } \\
\text { da Companhia Leopoldina, e sobre o pedido de um lugar } \\
\text { de amanuense na "Alfândega da Bahia". }\end{array}$ & $\begin{array}{c}\text {-íntima } \\
{[-} \\
\text { solidária] }\end{array}$ \\
\hline $\begin{array}{l}\text { Joaquim da Costa Barros } \\
\text { [Joaquim da Costa } \\
\text { Barros] (2JCB/carta 277) }\end{array}$ & $\begin{array}{l}\text { Escreve do Rio de Janeiro, } \\
\text { alfabetizado. } \\
\text { especificação de profissão) }\end{array}$ & $\begin{array}{l}\text { Excelentissimo } \\
\text { Senhor Doutor } \\
\text { Severino Vieira }\end{array}$ & $\begin{array}{l}\text { Assimétrica } \\
\text { ascendente }\end{array}$ & $\begin{array}{l}\text { Comunica ao Dr. Severino sobre o pedido de habaes } \\
\text { corpus do Sr. Santos. }\end{array}$ & $\begin{array}{c}\text {-íntima } \\
{[-} \\
\text { solidária] }\end{array}$ \\
\hline $\begin{array}{l}\text { Joaquim Mendes de } \\
\text { Souza (2JMS/cartas } 278 \\
\text { e 279) }\end{array}$ & 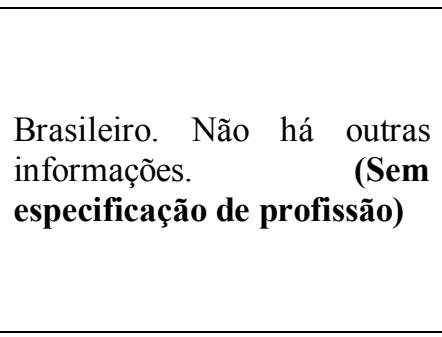 & $\begin{array}{c}\text { Excelentissimo } \\
\text { Companheiro e } \\
\text { Amigo Dr. Severino } \\
\text { (carta 278) } \\
\text { Excelentissimo } \\
\text { Compadre e amigo } \\
\text { Dr. Severino| (carta } \\
\text { 279) } \\
\end{array}$ & $\begin{array}{l}\text { Assimétrica } \\
\text { ascendente }\end{array}$ & $\begin{array}{l}\text { Comunica que a usina de Terra Nova começará a moagem } \\
\text { em breve. (Carta 278) } \\
\text { Comunica sobre o desfalque ocorrido com a estação de } \\
\text { Santo Amaro. (Carta 279) }\end{array}$ & $\begin{array}{l}\text {-íntimas } \\
{[-} \\
\text { solidária] }\end{array}$ \\
\hline $\begin{array}{l}\text { John } \quad \text { T. } \\
(2 \mathrm{JTL} / \text { carta } 280)\end{array}$ & $\begin{array}{l}\text { Estrangeiro s serviço no } \\
\text { Brasil. Carta escrita a pedido. } \\
\text { (Sem especificação de } \\
\text { profissão) }\end{array}$ & $\begin{array}{l}\text { Excelentissimo e } \\
\text { Illustrissimo Senhor } \\
\text { Dr. Severino dos } \\
\text { Santos Vieira }\end{array}$ & $\begin{array}{l}\text { Assimétrica } \\
\text { ascendente }\end{array}$ & $\begin{array}{l}\text { Informa sobre a exposição realizada em "St. Louis" em } \\
\text { 1903, em comemoração ao centenário de aquisição do } \\
\text { território de Louisiana, em } 1803 \text {. }\end{array}$ & $\begin{array}{c}\text {-íntima } \\
{[-} \\
\text { solidária] }\end{array}$ \\
\hline
\end{tabular}




\begin{tabular}{|c|c|c|c|c|c|}
\hline $\begin{array}{l}\text { José Doria } \quad(2 \mathrm{JD} / \text { carta } \\
281)\end{array}$ & $\begin{array}{l}\text { [Brasileiro], [Bacharel], } \\
\text { [maduro]. Procurador junto } \\
\text { à Viação do Brasil. }\end{array}$ & Severino & $\begin{array}{l}\text { Assimétrica } \\
\text { ascendente }\end{array}$ & $\begin{array}{l}\text { Informa sobre o recado dado pelo Paulo e diz que se } \\
\text { apressou em lhe escrever para "varrer" qualquer suspeita } \\
\text { de que o seu silêncio pudesse causar. Diz ter sabido sobre } \\
\text { viagem de Coelho e de Campos para Sergipe a fim de } \\
\text { tratar com o padre sobre assuntos relacionados a esse } \\
\text { estado. }\end{array}$ & $\begin{array}{l}\text {-íntima } \\
{[-} \\
\text { solidária] }\end{array}$ \\
\hline $\begin{array}{l}\text { Jose Julio de Freitas } \\
\text { Coutinho } \quad(2 \mathrm{JJFC} / \text { carta } \\
\text { 282) }\end{array}$ & $\begin{array}{l}\text { Carioca. Bacharel em Direito } \\
\text { (Faculdade de Direito de } \\
\text { Recife), } 28 \text { anos. Juiz de } \\
\text { Direito. }\end{array}$ & $\begin{array}{l}\text { Excelentissimo } \\
\text { Senhor Dr. Severino } \\
\text { Vieira }\end{array}$ & $\begin{array}{l}\text { Assimétrica } \\
\text { ascendente }\end{array}$ & $\begin{array}{l}\text { Diz estar à disposição do governador para exercer a sua } \\
\text { função de magistrado. }\end{array}$ & $\begin{array}{l}\text {-íntima } \\
{[-} \\
\text { solidária] }\end{array}$ \\
\hline $\begin{array}{l}\text { L. Samuel (2LS/cartas } \\
284 \text { e } 285)\end{array}$ & $\begin{array}{l}\text { Baiano. Bacharel em } \\
\text { Ciências Jurídicas e Sociais. } \\
46 \text { anos. Advogado. }\end{array}$ & $\begin{array}{l}\text { Illustrissimo } \\
\text { Excelentissimo } \\
\text { Senhor Dr. Severino } \\
\text { Vieira (cartas } 284 \text { e } \\
\text { 285) }\end{array}$ & $\begin{array}{l}\text { Assimétrica } \\
\text { ascendente }\end{array}$ & $\begin{array}{l}\text { Agradece a delicada lembrança entregue pelo Dr. Jerônimo } \\
\text { T. de Alencar Lima. (Carta 284) } \\
\text { Informa sobre carta recebida a respeito de um amigo em } \\
\text { comum. (Carta 285) }\end{array}$ & $\begin{array}{l}\text { +íntimas } \\
{[+} \\
\text { solidária] }\end{array}$ \\
\hline $\begin{array}{l}\text { Leão Velloso Filho } \\
\text { [Pedro Leão Velloso } \\
\text { Filho] }(2 \mathrm{LVF} / \text { carta } 286)\end{array}$ & $\begin{array}{l}\text { Baiano. Bacharel em Direito } \\
\text { (Faculdade de Direito de } \\
\text { Recife), } 46 \text { anos. Professor } \\
\text { da Faculdade Livre de } \\
\text { Ciências Jurídicas e Sociais } \\
\text { do Rio de Janeiro. }\end{array}$ & Meu caro Severino & $\begin{array}{l}\text { Assimétrica } \\
\text { ascendente }\end{array}$ & $\begin{array}{l}\text { Agradece as condolências do amigo pela morte de seu pai, } \\
\text { Leão Veloso. }\end{array}$ & $\begin{array}{l}\text { +íntima } \\
{[+} \\
\text { solidária] }\end{array}$ \\
\hline $\begin{array}{l}\text { Leoncio Correia }(2 \mathrm{LC} \\
\text { carta/287) }\end{array}$ & $\begin{array}{l}\text { Deputado Federal pelo } \\
\text { Paraná. Não há outras } \\
\text { informações. }\end{array}$ & $\begin{array}{l}\text { Excelentissimo } \\
\text { Senhor Doutor } \\
\text { Severino Viera }\end{array}$ & Simétrica & $\begin{array}{l}\text { Solicita a sua nomeação para "Administrador da } \\
\text { Imprensa", profissão já exercida por ele em sua cidade. }\end{array}$ & $\begin{array}{l}\text {-íntima } \\
{[-} \\
\text { solidária] }\end{array}$ \\
\hline $\begin{array}{l}\text { Leonel Rocha 2LR } \\
\text { (carta/288) }\end{array}$ & $\begin{array}{l}\text { Brasileiro. Não há outras } \\
\text { informações. } \\
\text { especificação de profissão) }\end{array}$ & $\begin{array}{l}\text { Meu caro Dr. } \\
\text { Severino }\end{array}$ & $\begin{array}{l}\text { Assimétrica } \\
\text { ascendente }\end{array}$ & $\begin{array}{l}\text { Apresenta o portador da carta, o Dr. Bouquet, antigo } \\
\text { engenheiro e gerente da companhia de gás do Rio, recém- } \\
\text { nomeado para gerir a companhia de gás da Bahia, onde vai } \\
\text { residir pela primeira vez. }\end{array}$ & $\begin{array}{l}\text {-íntima } \\
\text { [- } \\
\text { solidária] }\end{array}$ \\
\hline $\begin{array}{l}\text { L. de Bulhões [José } \\
\text { Leopoldo de Bulhões } \\
\text { Jardim] (2LB/carta 283) }\end{array}$ & $\begin{array}{l}\text { Goiano. Bacharel em Direito } \\
\text { (Faculdade de Direito de São } \\
\text { Paulo), } 45 / 46 \text { anos. Ministro. }\end{array}$ & $\begin{array}{l}\text { Excelentissimo } \\
\text { amigo Senhor Doutor } \\
\text { Severino Vieira }\end{array}$ & Simétrica & $\begin{array}{l}\text { Faz recomendações sobre o Sr. Almeida Couto, irmão do } \\
\text { Juiz de Direito do Rio Verde. }\end{array}$ & $\begin{array}{l}\text {-íntima } \\
{[-} \\
\text { solidária] }\end{array}$ \\
\hline
\end{tabular}




\begin{tabular}{|c|c|c|c|c|c|}
\hline $\begin{array}{l}\text { LeovigildoFilgueiras } \\
\text { [Leovigildo } \quad \text { Ipiranga } \\
\text { Amorim } \quad \text { Filgueiras] } \\
\text { (2LIAF/carta } 289 \text { ) }\end{array}$ & $\begin{array}{l}\text { Baiano. Bacharel em Direito } \\
\text { (Faculdade de Direito de } \\
\text { Recife), } 46 \text { anos. Deputado } \\
\text { Federal. Fundador da } \\
\text { Faculdade de Direito da } \\
\text { Bahia. }\end{array}$ & Severino & Simétrica & $\begin{array}{l}\text { Fala sobre o contratempo no encontro com o Ministro da } \\
\text { Viação, além de assuntos relacionados ao banco } \\
\text { Hipotecário. }\end{array}$ & $\begin{array}{l}\text {-íntima } \\
{[-} \\
\text { solidária] }\end{array}$ \\
\hline $\begin{array}{l}\text { Luiz H.LinsdeAlmeida } \\
\text { [Luiz H. Lins de } \\
\text { Almeida] (2LHLA/carta } \\
\text { 290) }\end{array}$ & $\begin{array}{l}\text { Brasileiro. Secretário da } \\
\text { Gazeta } \\
\text { Financeira. Nãorcial há outras } \\
\text { informações. }\end{array}$ & $\begin{array}{l}\text { Excelentissimo } \\
\text { Senhor Dr. Severino } \\
\text { dos Santos Vieira D. } \\
\text { D. Governador do } \\
\text { Estado da Bahia }\end{array}$ & $\begin{array}{l}\text { Assimétrica } \\
\text { ascendente }\end{array}$ & $\begin{array}{l}\text { Diz sobre providências junto ao Banco Nacional Brasileiro } \\
\text { e sobre negócios do governo do estado da Bahia sobre os } \\
\text { quais vem cuidando }\end{array}$ & $\begin{array}{c}\text {-íntima } \\
{[-} \\
\text { solidária] }\end{array}$ \\
\hline $\begin{array}{l}\text { M. Torres }(2 \mathrm{MT} / \mathrm{carta} \\
291)\end{array}$ & $\begin{array}{l}\text { Mulher madura com netos. } \\
\text { Não há outras informações. } \\
\text { (Sem especificação de } \\
\text { profissão) }\end{array}$ & $\begin{array}{l}\text { Excelentissimo Sr. } \\
\text { Dr. Severino Vieira }\end{array}$ & $\begin{array}{l}\text { Assimétrica } \\
\text { ascendente }\end{array}$ & $\begin{array}{l}\text { Solicita um emprego para o seu neto Arthur Nogueira que } \\
\text { está desempregado. }\end{array}$ & $\begin{array}{l}\text {-íntima } \\
{[-} \\
\text { solidária] }\end{array}$ \\
\hline $\begin{array}{l}\text { MWicks }(2 \mathrm{MW} / \text { cartas } \\
292 \text { e } 293)\end{array}$ & $\begin{array}{l}\text { Estrangeiro. Carta escrita a } \\
\text { pedido. Não há outras } \\
\text { informações. } \\
\text { especificação de profissão) }\end{array}$ & \begin{tabular}{l}
\multicolumn{2}{l}{ Excelentissimo } \\
Senhor Dr. Severino \\
Vieira Governador do \\
Estado da Bahia - \\
Bahia, Prezado \\
Senhor (carta 292) \\
Excellentissimo \\
Senhor $\quad$ Doutor \\
Severino \\
Governador Vieira \\
Estado da Bahia, \\
Amigo e Excellencia \\
(carta 293)
\end{tabular} & $\begin{array}{l}\text { Assimétrica } \\
\text { ascendente }\end{array}$ & $\begin{array}{l}\text { Fala do seu prazer ao receber o favor e comenta sobre } \\
\text { problemas relativos ao empréstimo feito pelo estado do } \\
\text { Pará. (Carta 292) } \\
\text { Apresenta o seu sócio, o Sr. C. F. Grundtvig, em viagem à } \\
\text { Bahia por três dias. (Carta 293) }\end{array}$ & $\begin{array}{l}\text {-íntima } \\
\text { [- } \\
\text { solidária] }\end{array}$ \\
\hline $\begin{array}{lr}\text { Manoel } & \text { Coelho } \\
\text { Rodrigues } & (2 \mathrm{MCR} / \text { carta } \\
294) & \end{array}$ & Piauiense. Jovem. Político. & $\begin{array}{c}\text { Illustrissimo e } \\
\text { Excelentissimo } \\
\text { Senhor Dr. Severino } \\
\text { Vieira }\end{array}$ & $\begin{array}{l}\text { Assimétrica } \\
\text { ascendente }\end{array}$ & $\begin{array}{l}\text { Comunica o seu casamento realizado em } 2 \text { de julho próxim } \\
\text { Madame Lucila Bastos, filha do Capitão Tenente João da C } \\
\text { Nessa longa carta, narra toda a trajetória política de seu p: } \\
\text { informando sobre a sua pretensão em seguir a carreira p } \\
\text { oportunidade, pede o apoio do amigo para a sua candidatura }\end{array}$ & $\begin{array}{c}\text { +íntima } \\
{[+} \\
\text { solidária] }\end{array}$ \\
\hline
\end{tabular}




\begin{tabular}{|c|c|c|c|c|c|}
\hline $\begin{array}{l}\text { Milciades de Sá Freire e } \\
\text { Augusto de Vasconcellos } \\
(2 \mathrm{MSF} / \text { carta 295) }\end{array}$ & $\begin{array}{l}\text { Brasileiro. Não há outras } \\
\text { informações. (Sem } \\
\text { especificação de profissão) }\end{array}$ & $\begin{array}{l}\text { Excelentissimo Amigo } \\
\text { Dr. Severino }\end{array}$ & $\begin{array}{l}\text { Assimétrica } \\
\text { ascendente }\end{array}$ & $\begin{array}{l}\text { Pedem apoio para Dr. João Buarque de Lima continue } \\
\text { como pretor da } 15^{\mathrm{a}} \text { Pretoria, após o término do seu } \\
\text { quatriênio a } 6 \text { de dezembro vindouro, a protegê-lo das } \\
\text { perseguições sofridas. }\end{array}$ & $\begin{array}{l}\text {-íntima } \\
\text { [- } \\
\text { solidária] }\end{array}$ \\
\hline $\begin{array}{lr}\text { Monsenhor } & \text { Guedelha } \\
\text { Mourao } & \text { [Deoclides } \\
\text { Correa } & \text { Guedelha } \\
\text { Mourão] } & \text { (2DCGM/carta } \\
296) & \\
\end{array}$ & $\begin{array}{ll}\text { Brasileiro. } & \text { Religioso. } \\
\text { Monsenhor. Não há outras } \\
\text { informações. }\end{array}$ & $\begin{array}{l}\text { Excelentissimo amigo } \\
\text { Severino Vieira }\end{array}$ & $\begin{array}{l}\text { Assimétrica } \\
\text { ascendente }\end{array}$ & $\begin{array}{l}\text { Pede apoio para a portadora da carta, D. Emerentina } \\
\text { Pereira de Castilho, viúva, que vive na mais honrada } \\
\text { pobreza. }\end{array}$ & $\begin{array}{l}\text {-íntima } \\
\text { [- } \\
\text { solidária] }\end{array}$ \\
\hline $\begin{array}{l}\text { Nuno de Andrade [Nuno } \\
\text { Ferreira de Andrade] } \\
(2 \text { NFA/cartas } 297 \text { e } 298)\end{array}$ & $\begin{array}{l}\text { Carioca. Médico (Faculdade } \\
\text { de Medicina do Rio de } \\
\text { Janeiro), } 51 \text { anos. Professor } \\
\text { da Faculdade de Medicina no } \\
\text { Rio de Janeiro. }\end{array}$ & $\begin{array}{c}\text { Excelentissimo } \\
\text { Senhor Doutor } \\
\text { Severino Vieira (carta } \\
\text { 297) } \\
\text { Excelentissimo } \\
\text { Amigo e colega } \\
\text { (carta 298) }\end{array}$ & $\begin{array}{l}\text { Assimétrica } \\
\text { ascendente }\end{array}$ & $\begin{array}{l}\text { Solicita auxílio na condição de funcionário e brasileiro e } \\
\text { fala sobre assuntos políticos. (Carta 297) } \\
\text { Fala do empenho em ajudar o amigo. (Carta 298) }\end{array}$ & $\begin{array}{l}\text {-íntima } \\
\text { [- } \\
\text { solidária] }\end{array}$ \\
\hline $\begin{array}{l}\text { Oliveira Coelho [José de } \\
\text { Oliveirar Coelho] } \\
\text { (2JOC/carta 299) }\end{array}$ & $\begin{array}{l}\text { Carioca. Bacharel em Direito } \\
\text { (Faculdade de Direito de São } \\
\text { Paulo), } 49 \text { anos. Delegado. }\end{array}$ & Meu caro Severino & $\begin{array}{l}\text { Assimétrica } \\
\text { ascendente }\end{array}$ & $\begin{array}{l}\text { Informa a ida do seu filho para Bahia, José de Oliveira } \\
\text { Coelho Jr. no vapor "Manaus" com o objetivo de continuar } \\
\text { os seus estudos na Faculdade de Direito da Bahia. Na } \\
\text { oportunidade, pede que dê o apoio necessário ao mesmo. }\end{array}$ & $\begin{array}{l}\text { +íntima } \\
\text { [+ } \\
\text { solidária] }\end{array}$ \\
\hline $\begin{array}{l}\text { Pedro José Oliveira } \\
\text { [Pedro José de Oliveira] } \\
(2 \mathrm{PJO} / \text { carta } 300)\end{array}$ & $\begin{array}{l}\text { Fiscal dos inflamáveis. Não } \\
\text { há outras informações. }\end{array}$ & $\begin{array}{l}\text { Prezado Amigo e } \\
\text { Chefe Dr. Severino } \\
\text { Vieira }\end{array}$ & $\begin{array}{l}\text { Assimétrica } \\
\text { ascendente }\end{array}$ & $\begin{array}{l}\text { Fala de assuntos políticos, demonstrando o seu apoio ao } \\
\text { amigo. }\end{array}$ & $\begin{array}{l}\text {-íntima } \\
\text { [- } \\
\text { solidária] }\end{array}$ \\
\hline Pires (2P/carta 301) & $\begin{array}{l}\text { Escreve de Pelotas. Não há } \\
\text { outras informações. (Sem } \\
\text { especificação de profissão) }\end{array}$ & Meu caro Severino & $\begin{array}{l}\text { Assimétrica } \\
\text { ascendente }\end{array}$ & $\begin{array}{l}\text { Solicita um emprego, o mais breve possível, devido a } \\
\text { grave situação que enfrenta. }\end{array}$ & $\begin{array}{l}\text {-íntima } \\
\text { [- } \\
\text { solidária] }\end{array}$ \\
\hline $\begin{array}{l}\text { Ramos Junior (2RJ/carta } \\
302)\end{array}$ & $\begin{array}{l}\text { Escreve do Rio de Janeiro. } \\
\text { Não há outras informações. } \\
\text { (Sem especificação de } \\
\text { profissão) }\end{array}$ & $\begin{array}{l}\text { Excelentissimo } \\
\text { Senhor Dr. Severino } \\
\text { dos Santos Vieira, } \\
\text { Meu prezado Amigo }\end{array}$ & $\begin{array}{l}\text { Assimétrica } \\
\text { ascendente }\end{array}$ & $\begin{array}{l}\text { Fala de sua felicidade ao receber o cartão de boas festas e } \\
\text { do cansaço da vida administrativa, ao tempo que se coloca } \\
\text { a disposição dos amigos. }\end{array}$ & $\begin{array}{c}\text { +íntima } \\
{[+} \\
\text { solidária] }\end{array}$ \\
\hline
\end{tabular}




\begin{tabular}{|c|c|c|c|c|c|}
\hline $\begin{array}{l}\text { Saldanha } \\
\text { Saldanha] } \\
\text { 303, 304, } 305,306 \text { e } \\
\text { 307) }\end{array}$ & $\begin{array}{l}\text { Brasileiro. Bacharel. } \\
\text { Secretário da Viação e } \\
\text { Obras Públicas no Governo } \\
\text { de Severino Vieira. }\end{array}$ & $\begin{array}{l}\text { Compadre e amigo } \\
\text { Dr. Severino (cartas } \\
303 \text { e } 304 \text { ) } \\
\text { Presado compadre e } \\
\text { bom amigo (carta } \\
\text { 305) } \\
\text { Presado Compadre e } \\
\text { amigo (cartas } 306 \text { e } \\
\text { 307) }\end{array}$ & $\begin{array}{l}\text { Assimétrica } \\
\text { ascendente }\end{array}$ & $\begin{array}{l}\text { Informa sobre Felícia e sobre peças compradas para a } \\
\text { locomotiva de Santo Amaro. (Carta } 303 \text { ) } \\
\text { Informa ao amigo sobre assuntos particulares e sobre } \\
\text { amigos em comum. (Carta 304) } \\
\text { Fala sobre as famílias, amigos em comuns e sobre política. } \\
\text { (Carta 305) } \\
\text { Informa sobre a família. (Carta 306) } \\
\text { Informa sobre assuntos envolvendo familiares. (Carta 307) }\end{array}$ & $\begin{array}{l}\text { +íntima } \\
{[+} \\
\text { solidária] }\end{array}$ \\
\hline $\begin{array}{l}\text { Serzedello Correa } \\
\text { [InnocêncioSerzedello } \\
\text { Corrêa] (2ISC/carta 308) }\end{array}$ & $\begin{array}{lcr}\text { Paraense. } & \text { Bacharel } & \text { em } \\
\text { Ciências } & \text { Fiscais } & \mathrm{e} \\
\text { Matemáticas. } & 43 & \text { anos. } \\
\text { Ministro. } & & \\
\end{array}$ & $\begin{array}{lcc}\text { Meu } & \text { caro } & \text { e bom } \\
\text { amigo } & \text { Sr. } & \text { Severino } \\
\text { Vieira } & & \end{array}$ & Simétrica & Apresenta o seu amigo particular, o artista Cobiano. & $\begin{array}{l}\text { +íntima } \\
{[+} \\
\text { solidária] }\end{array}$ \\
\hline $\begin{array}{l}\text { Tobias } \quad \text { [Monteiro] } \\
(2 \mathrm{TM} / \text { cartas } 309 \text { e } 310)\end{array}$ & $\begin{array}{l}\text { Potiguar. Médico. } 36 \text { anos. } \\
\text { Auxiliar de Gabinete do } \\
\text { Ministério da Fazenda. }\end{array}$ & $\begin{array}{l}\text { Meu caro Severino } \\
\text { (cartas } 309 \text { e } 310)\end{array}$ & $\begin{array}{l}\text { Assimétrica } \\
\text { ascendente }\end{array}$ & $\begin{array}{l}\text { Agradece o generoso artigo publicado no Diário acerca do } \\
\text { seu livro. (Carta 309) } \\
\text { Comunica que Paulo Guimarães irá falar verbalmente } \\
\text { sobre Filgueiras. (Carta 310) }\end{array}$ & $\begin{array}{l}\text {-íntimas } \\
\text { [- } \\
\text { solidária] }\end{array}$ \\
\hline
\end{tabular}

Fonte: Adaptado de Carneiro (2005, p. 104-108). 
Nas cartas analisadas, como se vê, as relações são relativizadas, fazendo com que a hierarquia, em alguns casos, seja ultrapassada pela relação de "igualdade" entre amigos.

\section{O SISTEMA DE TRATAMENTO NAS CARTAS PARA SEVERINO VIEIRA: A POSIÇÃO DE SUJEITO}

Foi obtido, na amostra, um total de $118^{16}$ dados, na posição de sujeito pleno, excluindo-se os casos de nulo. A forma nominal Vossa Excelência, dentre todas as formas de tratamento utilizadas, apresentou uma maior produtividade, somando um total de 90 dados, o que contabiliza $76.27 \%$ das ocorrências. Esse resultado corrobora uma das hipóteses do estudo de Marcotulio (2010, p. 116), segundo a qual tanto maior será a uniformidade do tratamento quanto maior for $\mathrm{o}$ grau de cerimônia e deferência.

Em seguida, há a forma Vossa Senhoria, com 14 dados, equivalendo a $11,86 \%$. Foram identificados 6 dados de Senhor (a), o que representa 5,08\% das ocorrências, 5 dados da forma Você, 4,24\%, e 3 dados da forma $T u$, com 2,55\%, conforme ilustrado na Figura 1:

Figura 1 - Percentuais de uso das formas de tratamento na posição de sujeito.

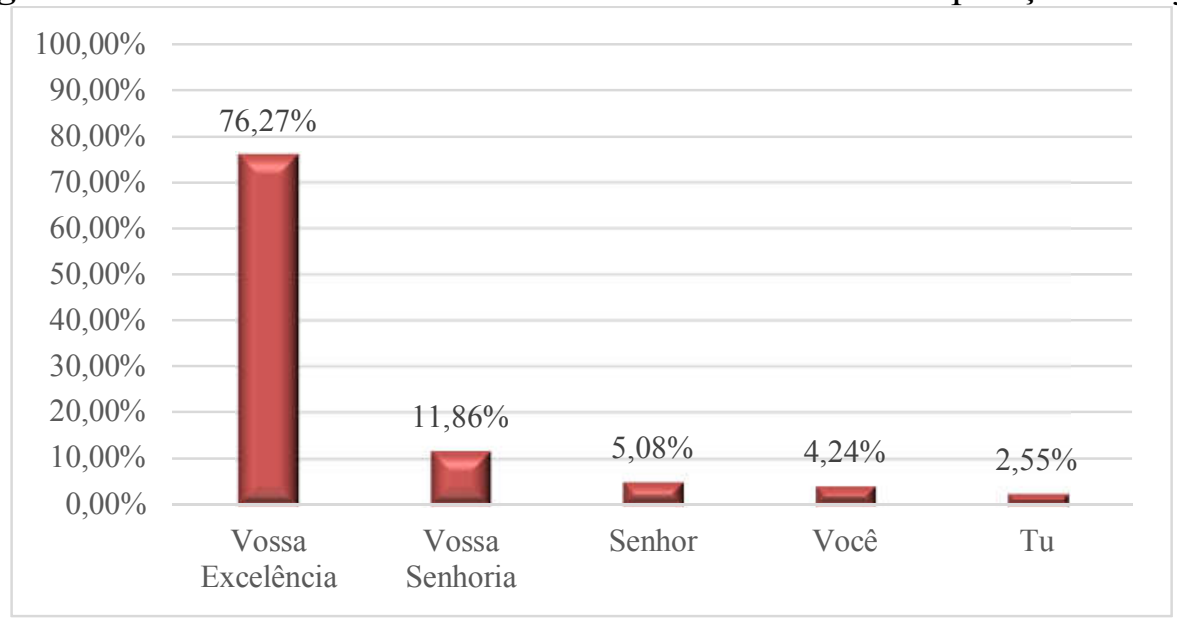

Fonte: Elaborada pelas autoras.

Os exemplos ${ }^{17}$ abaixo ilustram as ocorrências de Vossa Excelência, Vossa Senhoria, Senhor, Você e Tu.

\footnotetext{
${ }^{16}$ Nesta pesquisa, vale ressaltar, foram consideradas apenas as formas concretas realizadas na posição de sujeito.

${ }^{17}$ Em cada exemplo das cartas, há informações referentes a: nome da cidade, data de escrita, código do remente e número da carta, nesta mesma ordem.
} 


\section{(I) Vossa Excelência}

(1) [...] Pode Vossa Excelência encaminhar as| informações que solicito para| a rua de São Francisco xavier| n.61|[...] (Capital Federal, 28 de Outubro de 1901, 2AMP-211)

(2) [...] disponha (apenas trez praças), mas que espero Vossa Excelência mandará|augmentar logo que possivel, por ser esta localidade pon-|to de grande transito e sujeito apoder dar-se de momento|[...] (Timbó 20 d' Agosto de 1901, 2ASR-223)

(3) [...] como Vossa Excelência sabiamente disse em seu| relatorio na abertura da Assembleea e de que já estará sciente:| [...] (Timbó 20 d' Agosto de 1901, 2ASR223)

(4) [...] em conta a vinda dum auxiliar intelligente com que Vossa Excelência poderá contar, etc.|[...] (Timbó 20 d' Agosto de 1901, 2ASR-223)

(5) [...] VossaExcelência então, sob o fundamento de| que não contava no Governo da| União com elementos sufficientes| para me amparar, recusou-se| [...] (Capital Federal, 20-, 9-, 902, 2AAC-217)

\section{(II) Vossa Senhoria}

(6) [...] Vossa Senhoria soube dispensar-|-me é que mais uma vez solicito [...]. (Sem local, 7 de Março de 1902, 2AL-209).

(7) [... $\mid$ do com Sr.Barrow, neste dia Vossa Senhoria| apresentou-me a elle e prometeo| me um lugar de fiel <e amanuense $>$ da Alfandega| [...] (Rio 4 de Janeiro de 1902, 2JPD-276)

\section{(III) Senhor}

(8) $[\ldots]$ tendo $\mid$ o $\underline{\mathbf{S r}} \cdot<$ sido $>$ convidado pelo $\mid$ meu mando para| Padrinho della, peço $\mid$ o favor ${ }^{18}$ de mandar á| procuração para um| dos seus amigos aqui.| (Sem local, 24 de Maio, 2CPG-230)

(9) Desculpe encommodal-o| tantas veses, pois é o $\underline{\mathbf{S r}}$. $\mid$ o unico amigo quecon-|tamos e que poderá| proteger aos meus| filhos.| (Sem local, 24 de Maio 2CPG-230)

(10) [...] Peço com urgencia que o $\underline{\mathbf{S r}}$. me mande uma carta| recommendando o meu|[...] (Sem local, 24 de Maio, 2CPG-230)

\footnotetext{
${ }^{18}$ Rasurado.
} 


\section{(IV) Formas de paradigma de Vocêt}

(11) [...] 219 Rio, 3 de julho de 1901|[...] Meu Caro Severino [...] Desculpe ter lhe fallado com tanta franquiza e emo|ção de animo, é porque, como lhe disse, o meu inte-|resse individual está fóra de questão, não sou| obstaculo a cousa alguma.| [...]Bem avalio as linhas com que voce $\underline{\hat{e}}^{\mathbf{2 0}}$ se tem ouvido por| fazer fraca a crise economica e financeira que tem| assoberbado o Estado durante sua administração. | [ [...]velho amigo e collega muito obrigado excordeAragão (Rio, 3 de julho de 1901, 2A-219)

(12) $[\ldots] \mid$ E de ti, o que me contas? Na politica até aos $\mid$ olhos, já se sabe. E que bons pratinhos tem tido!| Que te saibam bem, que o que é de gosto regala| a vida. Sei de tudo pelas conversas com os amigos,| e porque, embora avesso ás agitações em que vocês, ,politicos, tem prazer em achar-se, d'ellas não| têm os olhos por amor dos queridos, que| [...] (Rio, 16- Setembro-1901, 2J- 273)

(13) $[\ldots]$ Optima saúde e a todos| os seus, aos quaes visito.| Recebi seo recado pelo Paulo,| e apresso-me em escrever-|lhe para varrer qualquer| suspeita que the causa o| meo silencio. Primeiro: a| sua carta ultima foi sem| resposta a uma minha, e| como vejo muitos sem pedi-|rem noticias suas, e são| elles pessôas com quem você| se corresponde, explico o facto| por occupações que lhe pri-|vão de escrever, e por isso| [...] (Rio, 28 de setembro de 1902, 2JD-281)

(14) [...]Morreu o Salviano! Bem podia| ser levantada a candidatura do nos-|so Nogueira, da Recebedoria es-|tadual. É verdade que me custou| tambem andar muito doente.| Como você uma vez me dis-|se que esse lugar era para gente| assim, não posso indicar outro.| [...] (Rio, 28 de setembro de 1902, 2JD-281)

(15) [...] O Senhor Dr. Bourguet é um cavalheiro de finol trato e de grande competencia na sua próffissão; assim estou certo de que você o| acolherá, com a costumada gentileza.| [...] (Rio, 6 Nov. 1901, 2LR-288)

Esses remetentes, que mantêm amizade com o destinatário governador, usam o pronome você para com Severino Vieira, forma menos polida do que as formas nominais, variando com $t u$ nas relações mais solidárias.

\footnotetext{
${ }^{19}$ As formas seguintes não foram contabilizadas, mas são indicativas de você. Há vários casos: "Diz V que não acredita que a Empresa possa con-|certar suas finanças enquanto não se fizer em| sua administração as economias que se estão| impondo, sendo seu grande luxo ter a Em|preza tres Directores e mais um Agente Geral, e| pergunta porque não ha um Director no logar onde| se concentrão os seos serviços." (Rio, 3 de julho de 1901, 2A-219); "Felizmente $\mathbf{V}$ conhece as minhas idéas a esse respeito.| Mas desde que foi imposto um Director residente| em Valença e que nenhum posto toma nos ne-|gocios da Empreza, era indispensavel a existencia| de um Agente Geral no Joazeiro." (Rio, 3 de julho de 1901, 2A-219). Esses dois exemplos são do mesmo remetente 2A, carta 219.

${ }^{20} \mathrm{O}$ desdobramento da abreviatura foi uma decisão do Editor, cf. normas de Edição do PHPB. Cf. Carneiro (2005)
} 


\section{(V) Formas de paradigma de Tu}

(19) [...] A| comadre, essa, não pode, sem demonstração pelo| passeio, acredito que tu ainda te lembres de mim| ou de nós: conheces que ella tem uma theoria| de chochice pela qual se igualem sem apre-|ciação. E nem tem direito de te queixar, quando| eu, se de tres em tres dias pelo menos, não| attesto palpavelmente que.......Excuso con-|cluir, porque até já foste ouvido em confiancia| sobre um caso a especie.... Os mais, se não| te escrevem, acreditem te o mesmo, e a caminho| [...] (Rio, 1 10-8-1901, 2J-272)

(20) [...] pedido que não acho indiscreto desde| que te declaro que o Campos Salles, tendo me mandado dizer| que se interessava pelo mesmo projecto, disse-me tambem| não se prendia elle á restricção, com que fez| a minha nomeação; e, assim, não tendo $\underline{\text { tu}}$, por parte| $\square$ d'elle, sciencia de que tenha interesse, ficas em muito| melhores condições para te oppor ao que não foi com-|binado de que elle poe sophismas o seu compromisso.| [...] (Rio, $\left.1^{\circ}-8-1901,2 \mathrm{~J}-272\right)$

(21) [...]Eu, ao menos, acho isto muito logico,| sensato e patriotico. Não falo ao Ruy por-|que tu o conheces perfeitamente: elle é amigo| dos dois interessados; e pedido, porem, vindo de| ti, Governador do seu Estado, que não dá ordem| mas intercede, a coroa toma ${ }^{21}$ outra posição, e elle| demonstrará por a + b que o substitutivo é o| cummulo da perfeição. Os Bulhões tambem acha| que seria conveniente escreveres, apezar da conside|ração com que elle me trata: elle, que já votou| contra a medida do substitutivo quando elle foi proposto| isoladamente, poderia aferil-o agora para| [...] (Rio, 12.3.1902, 2J-275)

O remetente $2 \mathrm{~J}$ ora usa $t u$, como nos exemplos acima, ora usa você, como na carta 281; sempre, portanto, tratamentos de menor polidez para com o governador. Suas estratégias, na interlocução com Severino Vieira, não incluem formas nominais da semântica do poder.

Figura 2 - Excerto das Carta 272 do remetente João [Käpk ou Kopke] com o uso de $t u$

\section{$1 \mathrm{v}$.}

[...]tanto, crer que o meu silencio seja esquecimento. A| comadre, essa, não pode, sem demonstração pelo| passeio, acredito que tu ainda te lembres de mim| ou de nós [...].

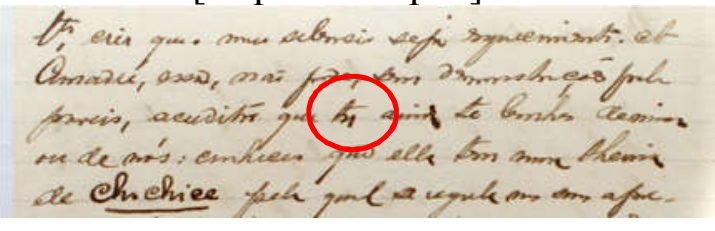

21 Rasurado. 
Figura 3 - Excerto das Carta 273 do remetente João [Käpk ou Kopke] com o uso de $6 r$.

[...]Sei de tudo pelas conversas com os amigos,| e porque, embora avesso ás agitações em que vocês, $\mid$ politicos, tem prazer em acharse, d'ellas não| têm os olhos por amor dos queridos, que| n'elles vejo anotados. Quanto a ti, folgo em| ver te subindo sempre e de dia em dia confir-| [...]

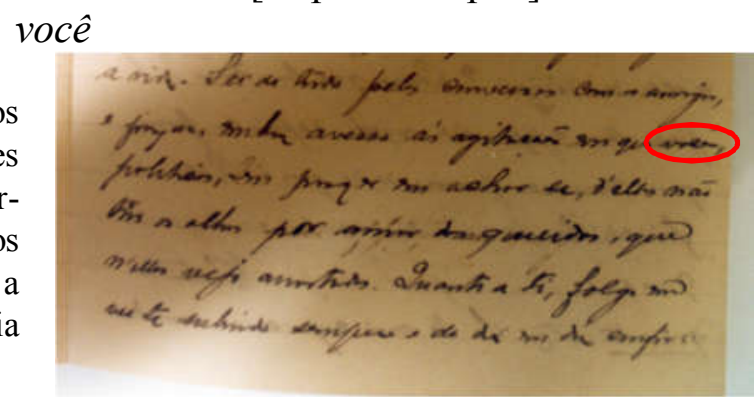

Não foram contabilizadas, como dito, as formas nulas; mas ressalta-se aqui que as formas de $t u$ nulo foram significativas no corpus. Vejam-se os exemplos a seguir:

\section{(VI) Formas de Tu Nulo}

(22) [...] Todos se te recommendam, embora um bocadinho| zangados porque não te desculpam o silencio,| que tens guardado, e não se contentam com a| demonstração da tua amizade no commando do| vôo, que vão tendo. [...] (Rio, 16- Setembro-1901, 2J-273-)

(23) [...]Para que comprehendes a mi|nha afflição, ja sabes que tal será a divi-|são que o meo officio poderá reduzir se á| renda do archivo, muito variavel, reduzida pelo| ultimo regimento, decrescente na razão directa| [...](Rio, 16- Setembro1901, 2J-273)

\section{CONSIDERAÇÕES FINAIS}

A análise do uso das formas de tratamento nas cartas do Acervo Severino Vieira revelou que:

I) Foram registradas como estratégias de referência à segunda pessoa do singular, na posição de sujeito, as formas Vossa Excelência, Vossa Senhoria, senhor, você e tu. Houve uma quantidade mais significativa das formas de tratamento de base nominal, se comparadas às formas pronominais. A forma Vossa Excelência apresentou o maior percentual de uso dentre as formas de tratamento analisadas na amostra, com 76,27\%, seguida de Vossa Senhoria, com 11,86\%.

II) A forma você ocorre em relações assimétricas ascendentes mais solidárias, o que é interessante. Foram 5 dados da forma você pleno. Seria maior esse número, tivessem sido contabilizadas as abreviaturas. 
III) Nas cartas em questão, o número de dados registrados de $t u$ pleno foi significativo, $2,55 \%$, apesar de pequeno, considerando tratar-se o destinatário de um Governador. Consideradas as formas nulas, esse número poderia aumentar muito.

Por fim, os dados aqui apresentados corroboram o que Lopes et al (2018), numa análise diatópico-diacrônica, verificaram sobre a forma gramaticalizada você - já bastante consolidada na primeira década do século XX -, isto é, que tem perdido a semântica do poder, ocorrendo em relações mais solidárias, variando com $t u$.

\section{REFERÊNCIAS}

BARBOSA, Afranio G. Para uma história do português colonial: aspectos lingüísticos em cartas de comércio. Rio de Janeiro: UFRJ. Tese de doutorado, 1999.

BRITO, O. R. M. de. Faça o mundo te ouvir: a uniformidade de tratamento na história do português brasileiro. 2001. Dissertação (Mestrado em Letras) Faculdade de Letras, Universidade Estadual de Londrina, Londrina, 2001.

; GILMAN, A. "The pronouns of power and solidarity". In: SEBEOK, T. Style in Language. Cambridge-Mass: MIT Press, 1960.

CARNEIRO, Zenaide de Oliveira Novais. Cartas brasileiras (1808-1904): um estudo linguístico-filológico. 2005. 4v. 2.329f. Tese (Doutorado em Linguística) - Instituto de Estudos da Linguagem, Universidade Estadual de Campinas, Campinas, São Paulo, 2005.

Cartas brasileiras (1809-2000): coletânea de fontes para o estudo do português. Feira de Santana: UEFS Editora, 2011. v 1.

. Cartas para Severino Vieira, governador da Bahia (1901-1902): edição fac-similada. In: Cartas brasileiras (1809-2000): coletânea de fontes para o estudo do português, CD-ROM 2. Feira de Santana: UEFS Editora, 2011. v. 1.

CE-DOHS. Corpus eletrônico de documentos históricos do sertão. Disponível em: <www.uefs.br/cedohs>. Acesso em: 10 ago. 2016.

CARREIRA, M. H. Modalisation Linguistique en Situation d'Interlocution. Proxémique verbale et modalités en portugais (Thèse de Doctorat deÉtat en Linguistique), Paris, Université de Paris IV- Sorbonne, 1995.

CARREIRA, M. H. Les formes d'allocution du portugais européen: valeurs et fonctionnements discursifs. Franco-British.

Studies, 35-45. 
http://cvc.cervantes.es/obref/coloquio paris/ponencias/pdf/cvc araujo.pdf). Acesso: 23 março de 2016.

CINTRA, L. F. L. Sobre "formas de tratamento" na língua portuguesa, 2a edição, Lisboa: Livros Horizonte, 1986.

CINTRA, L. F. L. Sobre “Formas de Tratamento" na língua portuguesa. Lisboa: Livros Horizonte/Coleção Horizonte, 1972.

FARACO, C. A. História da língua: uma introdução ao estudo da história das línguas. São Paulo: Parábola Editorial, 2005.

. O tratamento Você em português: uma abordagem histórica. In: Fragmenta. n. 13. Curitiba: Ed. da UFPR, 1996. p. 51-82.

GONÇALVES, M. F.; BANZA, A. P. Fontes de metalinguísticas para a história do português clássico. In: GONÇALVES, M. F.; BANZA, A. P. Património Textual e Humanidades Digitais: da antiga à nova filologia. Évora: CIDEHUS, 2013. p. 73-112.

LACERDA, M. F. de O.; DE ANDRADE, A. L.; CARNEIRO, Z. de O. N. Formas tratamentais em cartas baianas: sujeito e outras funções. Cadernos de Estudos Linguísticos (UNICAMP). v.2, p. 257-276, 2016.

LACERDA, M. F. de O. et al. Formas tratamentais no semiárido baiano: contribuições para uma configuração diatópico-diacrônica do sistema de tratamento do português brasileiro In: A Fala nordestina: entre a Sociolinguística e a Dialectologia. 1 ed. Salvador: Uneb, 2016, v.1, p. 32-52.

LOPES, Célia Regina dos Santos; DUARTE, Maria Eugênia Lamoglia. "De 'Vossa Mercê'a 'você': a pronominalização de nominais nos séculos XVIII e XIX" . Comunicação apresentada no XVII Encontro Nacional da ANPOLL. Gramado, UFRS, 2002.

LOPES, C. R. S.; MACHADO, A. C. M. Tradição e inovação: indícios do sincretismo entre a segunda e a terceira pessoas nas cartas dos avós. In: LOPES, C. R. S. (Org.). A norma brasileira em construção: Fatos linguísticos em cartas pessoais do século 19. Rio de Janeiro: UFRJ/FAPERJ, 2005. p. 45-66.

LOPES, C. R. S. Retratos da variação entre "você" e "tu" no português do Brasil: sincronia e diacronia. In: RONCARATI, C.; ABRAÇADO, J. (Org.). Português Brasileiro II: contato linguístico, heterogeneidade e história. Niterói: Ed. da UFF, 2008. v.2. p. 55-71.

LOPES, C. R.S. et al. A reorganização do sistema pronominal de $2^{\mathrm{a}}$ pessoa na história do português brasileiro: a posição de sujeito In: CASTILHO, A. (Org.). História do português brasileiro: mudança sintática das classes de palavra: perspectiva funcionalista.1 ed. São Paulo: Contexto, 2018, v.1, p. 24-141. 
MACHADO, A. C. M. As formas de tratamento nos teatros brasileiro e português dos séculos XIX e XX. 2011. Tese (Doutorado em Língua Portuguesa). Rio de Janeiro: Faculdade de Letras/ UFRJ, 2011.

MARCOTULIO, L. L. Língua e História: o 2 Marquês do Lavradio e as estratégias linguísticas da escrita no Brasil Colonial. v. 1. Rio de Janeiro: Ítaca Comunicações, 2010.

MARCOTULIO, L. L; SOUZA, P. L.” A Teoria da Polidez de Brown e Levinson aplicada ao português brasileiro: desafios e propostas". In: Semana Nacional de Estudos Linguísticos e Filológicos, 9, 2007, Rio de Janeiro. Anais. Rio de Janeiro: Círculo Fluminense de Estudos Filológicos e Linguísticos, 2007.

; SILVA, P. F.; LOPES, C. R. S. A norma brasileira em construção: variação tu e você no início do século XX. In: II Congresso Internacional da Associação Internacional de Linguística do Português (AILP). Rio de Janeiro, 2007.

MARTINS, Marco Antônio et al. "Para um panorama sócio-diacrônico das formas de tratamento na função de sujeito na região Nordeste". LaborHistórico, v.1, n.1, p. 26-48, 2015.

PROJETO CE-DOHS: Corpus eletrônico de documentos históricos do sertão. Coordenação: Zenaide de Oliveira Novais Carneiro; Mariana Fagundes de Oliveira. Disponível em: <www.uefs.br/cedohs > Acesso em 05 ago. 2016.

RODRIGUES, D.F. Cortesia Linguística. 2003. (Tese de doutoramento), Lisboa, Faculdade de Ciências Sociais e Humanas da Universidade Nova de Lisbo, 2003.

RUMEU, M. C. de B. RUMEU, Márcia Cristina de Brito. A implementação do "Você" no português brasileiro oitocentista e novecentista: um estudo de painel. 2008. Tese (Doutorado em Língua Portuguesa). Rio de Janeiro: UFRJ Faculdade de Letras, 2008.

. Para uma História do Português no Brasil: Formas Pronominais e Nominais de Tratamento em Cartas Setecentistas e Oitocentistas. 2004. Dissertação (Mestrado em Língua Portuguesa). UFRJ - Faculdade de Letras, Rio de Janeiro, 2004.

SOTO, E. U. M. S. Cartas através do tempo: o lugar do outro na correspondência brasileira. Niterói: Ed. da UFF, 2007.

. Variação/mudança do pronome de tratamento alocutivo: uma análise enunciativa em cartas brasileiras. 2001. Tese (Doutorado em Linguística) Faculdade de Ciências e Letras, Universidade Estadual Paulista, Araraquara, 2001.

TEYSSIER, P. História da Língua Portuguesa. São Paulo: Martins Fontes, 1997. 
TUY BATISTA, P; CARNEIRO, Z de O. N.; LACERDA, M. F. de O. $A$ variação tu/você em relações de solidariedade: análise de uma documentação baiana epistolar do século XX. CONFLUÊNCIA. v.2, p. 100-121, 2017.

Marinalda Freitas Valentim

MarinaldaFreitas@gmail.com

Mariana Fagundes de Oliveira Lacerda MarianaFag@gmail.com

Zenaide de Oliveira Novais Carneiro

Zenaide.Novais@gmail.com

Recebido em: 10 mar. 2018 Aceito em: 10 jun. 2018

Publicado em: 19 ago. 2018 